University of Rhode Island

DigitalCommons@URI

Open Access Master's Theses

1980

\title{
COMPUTER SIMULATION OF CHANGES IN TOWN'S GROWTH POLICIES
}

James Gilbert Palma Jr.

University of Rhode Island

Follow this and additional works at: https://digitalcommons.uri.edu/theses

\section{Recommended Citation}

Palma, James Gilbert Jr., "COMPUTER SIMULATION OF CHANGES IN TOWN'S GROWTH POLICIES"

(1980). Open Access Master's Theses. Paper 390.

https://digitalcommons.uri.edu/theses/390

This Thesis is brought to you for free and open access by DigitalCommons@URI. It has been accepted for inclusion in Open Access Master's Theses by an authorized administrator of DigitalCommons@URI. For more information, please contact digitalcommons-group@uri.edu. 
COMPUTER SIMULATION OF CHANGES

IN TOWN'S GROWTH POLICIES

BY

JAMES GILBERT PALMA, JR.

A THESIS PROJECT SUBMITTED IN PARTIAL FULFILLMENT OF THE

REQUIREMENTS FOR THE DEGREE OF

MASTER OF COMMUNITY PLANNING

UNIVERSITY OF RHODE ISLAND

1980 


\section{MASTER OF COMMUNITY PLANNING THESIS PROJECT \\ OF \\ JAMES GILBERT PALMA, JR.}

\section{Approved:}

Thesis Project Committee

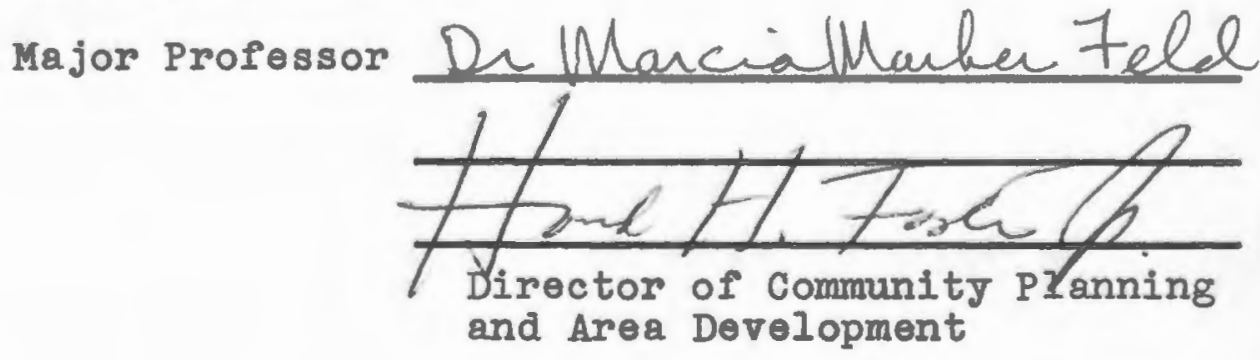

UNIVERSITY OF RHODE ISLAND 


\section{LIST OF TABLES}

II-1. Rules for Model Design

II-2. Time Required to Implement Nongrowth

$$
\text { Analysis Model }
$$

II-3. Quantifiable Variables Initially chosen

II-4. Actual Quantifiable Variables Used With

Their Source 22

III-1. System Flow Chart 39

III-2. Residual Patterns 44

A-1. New Privately Owned Housing Units Authorized by Permit 50

A-2. Public School Enrollment For Local Educational Agencies by Residence, $\mathrm{K}-12$

A-3. Net Residential Expenditures For Local Educational Agencies 52

A-4. Total Debt Service Payments For Local Educational Agencies 53

A-5. Municipal Expenditures For Public Safety 54

A-6. Full Assessed Valuation Contributed by Residential Class $\quad 55$

A-7. Model for South Kingstown, Rhode Island 56

A-8. Model for North Kingstown, Rhode Island 58

A-9. Model for Jamestown, Rhode Island 60

A-10. Student's t-Distribution 62

A-11. Five Percentage Points of F-Distribution 63

A-12. Durbin-Watson Statistic Distribution 65 


\section{TABLE OF CONTENTS (CONTINUED)}

III. USER'S MANUAL (CONTINUED)

Statistical Analysis

How to Use the Results

Summary

APPENDIX

BIBLIOGRAPHY

66 


\section{TABLE OF CONTENTS}

Introduction

Chapter

I. EXISTING GROWTH MODELS: A REVIEW OF THE LITERATURE

II. MODEL DESIGN

Introduction

Purpose

Quantifiable Variables

Variables Under Control of Planner

Aggregation

Time

Theories

Techniques

Data Availability

Methods of Calibration and Testing

Summary

III. USER'S MANUAL

As sumptions

Applications

Uses of Model

Limitations

Alternative Method

Findings

South Kingstown, Rhode Island

North Kingstown, Rhode Island

Jamestown, Rhode Island

Explaination of Algorithm

Input Data

Missing Data

How to Run the Program

What to Look For in the output 
A Thesis Project requires a great deal of time and energy on the part of the Master's candidate. However, the demands of this project were lightened by the unrelenting work of another. To this person I dedicate the ideas, time and energy that went into this project. This would only be proper, since her efforts and ideas are reflected on each page of this project.

Thank you Lynne. 


\section{Introduction}

In times of great economic uncertainty, the ability of municipalities to meet the ever increasing demands of its residents has become one of the major concerns of local government. Local government hears the demands for more and better schools, better police and fire protection, have better local services, yet have to face a great reluctance from residents to pay a higher tax for these improvements. Municipalities are addressing this dilemma by suggesting ways to limit or slow the growth of their residential sector.

This study suggests a method in which the average planning department can evaluate selected basic indicators of growth in their own municipality by using a multiple regression technique. Utilizing the regression equation, the planner can then infer the outcomes of different limited or nongrowth strategies.

Information that is most readily available to planning departments was identified and used. The regression equation calculations were performed on a widely available computer statistical package called Statistical Package For The Social Sciences (SPSS). This package is available at most 
computer installations (i.e. state computer installations, Universities, Colleges, and computer vendors). The purpose was to show that the methods described in this study are readily available to planners.

This document is in two parts. The first is the "Model Design" section. This section discusses the purpose of the model, the actual theories and techniques used and data availability. In general, it describes the work necessary to formulate a model.

The second section is the "User's Manual." This reviews the assumptions, applications and limitations of the model. Then a step by step list of instructions on how to set up, run, and analyze the model is provided. The last part presents a way of using the results of the model. 
CHAPTER I 


\section{Existing Growth Models: A Review of the Literature}

Most people realize that when a town or city grows, the local government must provide additional services to those new residents. The question which arises is that of the cost to the local government and the ability to pay the increased costs from future tax revenues. The response to this question was attempted by walter Isard in his book Municipal Costs and Revenues Resulting From Community Growth $^{1}$. In Isard's book he tabulates all municipal expenses and revenues for the major local government functions. By comparing the costs to the revenues he determined if the municipality should go through with the project.

Today, this procedure is not possible with the dynamic state of economic and political affairs. Isard's figures applied well in the late $1950^{\prime} \mathrm{s}$ and early $1960^{\circ} \mathrm{s}$ because growth was at a regular and predictable rate as was the economy.

Today people are very mobile, they tend to move when there are better living conditions and/or better employment opportunities. Currently, there are numerous residen- 
tial location models that try to predict where residential communities will locate.

One such model is discussed by Benjamin Zycher in Municipal Service Pricing: Impact on the Growth of Residential Development $^{2}$. Zycher discusses the impacts on residential locations when municipal service prices change. His focus is from the developers point of view, therefore he tries to determine where the developer will most likely build residential developments with the minimum expense (minimum municipal service charge).

Another model is A Model of Residential Values ${ }^{3}$ by E. F. Brigham. This model determines the value of residential land as determined by the distance away from the central Business District (CBD). It assumes that land located closer to the CBD is more valuable.

Stanislaw Czamanski takes a different approach to urban growth. He developed a model that calculates the potential for economic growth ${ }^{4}$. By knowing what economic potential an area has and assuming that residential communities will locate near economic centers (employment centers) then one can predict where, and to what extent residential growth will take place.

These depict the types of models that are currently available which deal with residential growth. These models either predict where residential communities will locate or to what degree the residential growth will be. 
6

"The subject matter of the nongrowth issue is rather poorly defined and largely unexplored in any comprehensive manner. Much more systematic field work is needed at the local level to build upon the emergence of nongrowth sentiment." 5

These words of Earl Finkler in 1974 are still true. The issue of slowing or stopping growth has not been studied sufficiently to permit local governments to make rational decisions on this matter.

The only method that is currently available which addresses the nongrowth issue is the Fiscal Impact Analysis.

"Fiscal impact analysis is a projection of the direct, current, public costs and revenues associated with residential or nonresidential growth to the local jurisdiction(s) in which the growth is taking place."6

This is very similar to the system set up by Isard in 1957. The major differences are the step by step procedures which are explained and quantified, and the information which is more complete and up-to-date.

The procedure that is followed in addressing nongrowth issues first determines the fiscal impact of continued growth. Then a second analysis of nongrowth is made, finally a comparison of the two analyses is made.

A good example of this comparison method was done by Gruen Gruen \& Associates in 1972.7 The study area was Santa Clara County, California. The study is very detailed and comprehensive, it evaluated everything from public school enrollment to the revenues generated through the county water supply.

The major problem with the Gruen Gruen study that most 
planners would have with this method is one of the study's best assests, it's comprehensiveness. The average planning department does not have the personnel or the budget to evaluate growth versus nongrowth on such a detailed scale as done by Gruen Gruen \& Associates.

In addition to the above limitations, additional problems have surfaced in recent literature. Richard B. Stern of Barton-Ashman Associates points out that "danger lurks in the underlying assumptions [of impact analysig]. Not all pitfalls [he describes eight pitfalls] lie in wait for every fiscal impact analyst, but most analysts will encounter at least one." 8 These pitfalls cover areas of overestimation of figures, not knowing when to use other approaches, and insufficient amount of time devoted to the presentation of the conclusions.

This review of the literature about growth models indicates most small and mid-size planning departments have little professional support to draw upon when it is faced with decisions concerning growth and nongrowth. This study will explore and test a method of analyzing growth indicators as a suggested way to assist planning departments in evaluating the effects of nongrowth strategies. 
FOOTNOTES

Chapter I

${ }^{1}$ Walter Isard et al., Municipal Costs and Revenues

Resulting From Community Growth, (Wellesley, Massachusetts: Chandler-Davis Publisher, 1957).

${ }^{2}$ Benjamin Zycher et al., Municipal Service Pricing: Impact on the Growth of Residential Development, (Santa Monica: The Rand Corporation, November 1975).

${ }^{3}$ E. F. Brigham, A Model of Land Residential Values, (Santa Monica: The Rand Corporation, 1965).

${ }^{4}$ Stanislaw Czamanski, "A Model of Urban Growth," Regional Science Association Papers 13 (1964): 177-200.

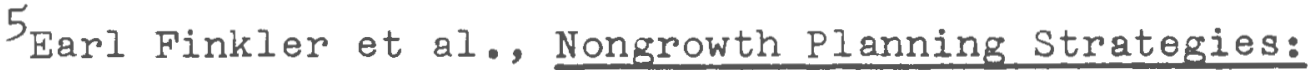
The Developing Power of Towns, Cities, and Regions, (New York: Praeger Publishers, 1974), p. vii.

${ }^{6}$ Robert $W$. Burchell et al., The Fiscal Impact Handbook, (New Brunswick, New Jersey: The Center For Urban Policy Research, 1978), p. 1.

7 Gruen Gruen \& Associates, Impacts of Growth: An Analytical Framework and Fiscal Examples, (California: California Better Housing Foundation, 1972).

${ }^{8}$ Richard B. Stern et al., "Beware the Pitfalls in Fiscal Impact Analysis," Planning 46 (April 1980): p. 15. 
CHAPTER II 


\section{Model Design}

\section{Introduction}

The method of model design utilized in this study was based upon the work of A. G. Wilson. ${ }^{1}$ Wilson set up nine rules for model design. These rules are stated in question form (see table II-l). One can design an appropriate model by answering these questions.

\section{Purpose}

To construct a method that the small to middle size planning department can use to evaluate the implementation of nongrowth (or limited growth) strategies.

The major constraints of a planning department are time and money. Therefore, the evaluation method must not require the purchase of sophisticated equipment or the special talents that only a few large planning departments have, such as a computer programmer. It cannot require large commitments by the staff, or the expenses of hiring a consultant to set up the system. Instead, the model must be 
understandable to a person who has a reasonable higher education (Bachelor's degree is a minimum).

TABLE II-I

RULES FOR MODEL DESIGN

1. What is the purpose behind the particular model building exercise?

2. What should be represented as quantifiable variables within the model?

3. Which of these variables are under the control of the planner?

4. How aggregated a view can be taken?

5. How should the concept of time be treated?

6. What theories are we trying to represent in the model?

7. What techniques are available for building the model?

8. What relevant data are available?

9. What methods can be used for the calibration and testing of the model?

SOURCE: A. G. Wilson, Urban and Regional

Models in Geography and Planning, John Wiley \&

Sons, Ltd., Bristol, England, 1974, pg. 31.

NOTE: The keywords in each rule are underlined by the author.

The method developed for this project requires a planner with the knowledge of basic statistics, the ability to follow very rigid procedures listed in this report along with understanding the regression section in the statistical Package For The Social Sciences (SPSS) manual. 2 The time requirement necessary to set up this model is as follows: 
TABLE II-2

TIME REQUIREMENTS TO IMPLEMENT NONGROWTH ANALYSIS MODEL

\begin{tabular}{|c|c|c|}
\hline Activity & & ime \\
\hline $\begin{array}{l}\text { Comprehension of model } \\
\text { and techniques }\end{array}$ & & Week \\
\hline Data selection & 1 & Week \\
\hline Data collection & $2-3$ & Weeks \\
\hline $\begin{array}{l}\text { Prepare data for } \\
\text { input to model }\end{array}$ & 1 & Week \\
\hline $\begin{array}{l}\text { Run model until the } \\
\text { model is statistically } \\
\text { significant }\end{array}$ & 2 & Weeks \\
\hline Interpretation of results & 1 & Week \\
\hline $\begin{array}{l}\text { Final conclusions and } \\
\text { preparation for pre- } \\
\text { sentation }\end{array}$ & & Weeks \\
\hline Total time required & $10-11$ & Weeks \\
\hline $\begin{array}{l}\text { NOTE: These time rec } \\
\text { the actual time that this } \\
\text { ures take into considerati } \\
\text { always accompany this type } \\
\text { equals a forty hour work }\end{array}$ & $\begin{array}{l}\text { ts are } \\
\text { took. } \\
\text { reseen } \\
\text { ject. }\end{array}$ & $\begin{array}{l}\text { based on } \\
\text { These fig- } \\
\text { delays which } \\
\text { One week }\end{array}$ \\
\hline
\end{tabular}

Quantifiable Variables

In determining what quantifiable variables should be used, constant attention was paid to their availability (which will be discussed in the "Data Availability" section). By examining other growth models and asking the questions, what indicators change when growth changes? or what causes growth? the following group of variables were selected. 
TABLE II-3

QUANTIFIABLE VARIABLES INITIALLY CHOSEN

1. Number of privately owned housing units authorized by permit

2. School enrollment by residence for grades $\mathrm{K}-12$

3. Cost of local educational agencies

4. Cost of public safety

5. Municipal crime rate

6. Equalized tax rate

7. Percent of residential property tax collected to the total tax collected

8. Cost of housing

9. Per capita income

10. Conventional mortgage rate

As will be seen in the "Data Availability" section, this list of ten variables was refined to six independent variables and one dependent variable.

The purpose of this model is to evaluate the implementation of different forms of growth strategies, and therefore, one of these variables must represent growth. The variable representing growth is the number of new privately owned housing units authorized by permit. This variable will be the dependent variable, while all other are the independent variables.

Variables Under Control of Planner

The only variable that could be considered as under 
14

the control of the planner is the measure of growth, which is the number of new building permits. However, the planner's control begins and ends with zoning and subdivision approval, after that stage he is not in control. The planner may control the total number of residential units, but he cannot control when they will be ready for inhabitance. The planner can control growth through a number of techniques. The most common techniques are moratoriums, downzoning, batching of development applications, interim zoning, timing and phasing strategies and developer exactions. ${ }^{3}$

A moratorium is when the town decides that it will no longer be able to provide essential services to its residents if the number of residents increase. Moratoriums are only legal if the health, safety, and welfare of the present residents would be placed in jeopardy if a moratorium was not instituted. One example would be that the capacity of the local sewage treatment plant had been reached. Therefore, now new housing would be allowed until the capacity was increased, or satisfactory individual septic systems could be installed.

Downzoning is when land is rezoned to a less intensive use. This growth control method only works if the present use of the land is less than or equal to the intensity of use perscribed in the newly downzoned district.

Interim zoning is used quite frequently. It is when a town realizes that it needs to make a formal growth pol- 
icy and set up measures to implement them, but needs time to create and adopt such a plan. By setting up interim zones, which only last for a specified amount of time, it makes it easy to rezone when the formal growth policies have been adopted.

Batching development applications helps the planner establish when the bulk of the new housing will be ready for inhabitance. Therefore, the planner is controlling when the growth will occur.

Timing and phasing strategies are very similiar to batching. The major difference is that timing and phasing splits up a single development and establishes when the units will be ready to live in, where batching combines many development projects together so that all the units can be controlled as to when people can move in.

Finally, developer exactions are dedications of land to the town for park or schools or for other public facilities. This method provides the town with land needed to provide local services to those new residents.

\section{Aggregation}

Aggregation is the process by which information is assembled together so that different types of information may be compared. The common base that was chosen is time in years. Therefore, all data had to be aggregated into annual form. 
If the information was available by month then the mean was taken as the annual figure. If there were just a few (less than three) data points missing then a simple linear interpolation was performed, otherwise they were left blank. (All missing data will be statistically interpolated internally by the regression program in SPSS.)

In the more general sense, all data should be disaggregated for each municipality, unless a variable that specifically is not describing its locality can be applied. An example of this special situation would be when a regional or national mortgage rate is used because the specific rate is not available, yet this is still a good indicator because the actual rate in its locality may only be slightly different.

Time

The concept of time is similiar to the process of aggregation. All of the data will be presented in a "time series" format. A time series shows all of the data for one study (or one municipality) listed according to some segment of time. As specified in the aggregation section, the time segment will be one year.

Theories

(Hypothesis)

The hypothesis of this study is: when a municipality 
changes its growth policy, an impact will occur on the amount of personal property taxes, housing costs, provisions of public services, and the percent of taxes collected from the residential sector.

As an illustration, when a municipality implements a nongrowth or limited growth strategy then personal property taxes will increase. This is thought to be true because the cost of current services will probably continue to rise. Since no new residents will move in to help defray these increased costs, the current residents will have to absorb the higher costs in the form of higher taxes. However, this will not be the case if new industrial and commercial activities are allowed in the municipality. But, for this analysis, these factors are generally considered exogenous.

The cost of housing is expected to rise over the current rate of appreciation. This is because the supply of housing is now limited, while the demand is less limited. This statement assumes that the area is a desirable place to live.

The provision of public services, such as police and fire protection, road maintenance, and quality of education are expected to decline. This is due to the similiar argument as explained above, which is that the costs of current services will continue to rise, yet there will only be a limited increase in the number of people who could cover the increased costs.

As for the percent of taxes received from the residen- 
tial sector, it is expected to rise unless there is an increase in industrial and commercial activities. However, this scenario is unlikely. An effort to increase industrial activity could create more jobs which in turn could mean a demand to build more housing. When a locality decides to limit growth then the market itself will limit the growth of commercial activities. Therefore, the contention that the percent of residential taxes will rise seems firm.

\section{Techniques}

Using residential growth rate (determined by the number of new private building permits that were issued for each year) as the dependent variable, a regression analysis will be performed using the remaining variables as independent variables (for a final list of the variables see the "Data Availability" section). The adjustment of data and variables in order to show an acceptable linear correlation between the independent variables and the dependent variable is the next step. (A complete procedural description can be found in the "Statistical Analysis" section of the User's Manual chapter).

By definition the calculated coefficients $\left(B_{i}\right)$ in equation ( 1 ) of each of the independent variables $\left(x_{i}\right)$ in the regression explain how that independent affects the dependent variable ( $Y$ ).

$$
Y=B_{0}+B_{1} X_{1}+B_{2} X_{2}+\ldots B_{n} X_{n}
$$


As presented in equation (2), the assessed valuation of residential property (ASSESSVA) affects the number of new residential building permits (BUILDPER) by a factor of +0.514 and the public safety expenditures (SAFETYEX) affect on building permits is - 0.1266 .

$$
\begin{aligned}
\text { BUILDPER }= & 0.514(\text { ASSESSVA })-0.162(\text { SCHLENOL }) \\
& +0.044(\text { SCHOOLEX })+0.254(\text { SCHLDEBT }) \\
& -0.126(\text { SAFETYEX })+428.9
\end{aligned}
$$

These regression coefficients show the effects of each independent variable impacting together on new building permits.

At this point, most regression models evolve into forecasting models. They extrapolate future values for each of the independent variables, then insert those predicted values into the regression equation and predict a new dependent variable.

The major underlying assumption with traditional forecasting procedure is that each of the future calculated independent variables will continue to behave in a similiar fashion as its past history indicates. This, however, is not the behavior of the independent variables in this study. Specifically, the past history is consistant, but the future independent variable value cannot be determined by traditional methods. This is due to the current day dynamics of the economy, and thus is reflected in the growth indicators 
that are identified for this study. Given this present state of change, the planner may only be able to predict on a one year interval. Planners must be in close communication with the local agencies responsible for the policies and decisions that will affect these variables. For example, the planner must keep in communication with the tax assessor, (so that a "valid value" for next years tax assessment will be used in the model). The planner must be aware of any new assessment policies, such as a reassessment or a new mill rate. All of these policies will directly affect the amount of tax collected (which is an independent variable) and indirectly affects the growth in the residential sector (as described in the regression equation).

Data Availability

While developing a new theory or testing a hypothesis an important aspect is "thinking the problem through," and determining the pitfalls and its limitations. But, the most significant step in the success of designing a model is the availability of data. If one can locate data which is already aggregated which meets the needs of the model it will substantially establish its validity.

Lack of available data has been a major constraint throughout this study. The most recurring availability problem is that the data needed, such as housing costs, are arailable in highly aggregated forms, for example, listed by 
state, region, county or Standard Metropolitan Statistical Area (SMSA) instead of locality. A similiar problem was the actual publishing of material. Many state and federal agencies collect local information but they do not publish for each separate locality, instead it is pooled with other similiar localities.

However, if an agency collects data, usually a back catalog is kept on microfilm or microfiche. This information can be requested by a simple phone call to the appropriate agency. Tre following discussion will review the process and problems which led to the list shown in table II-4 of Actual Quantifiable Variables Used, along with their source. The number of new privately owned housing units that were authorized by local building permits still remains the surrogate indicator for residential growth. The best source for the building permits is the annual Construction Reports, C-40 Series, Table 4, from the Bureau of the Census. It should be pointed out that the government publication catalogs have changed three times in the past thirty years. If there are still problems in locating complete information, the Census Bureau staff for the Construction Reports are available to research the needed information.

The public school enrollment, the net residential expenditures for schools as well as the debt service payments for schools are available either in the local budgets or in a state report by the Department of Education. The title of such a report in Rhode Island is the Statistical Tables pub- 
lished by the Rhode Island Department of Education, Division of Research and Planning.

TABLE II -4

ACTUAL QUANTIFIABLE VARIABLES USED WITH THEIR SOURCE

1. New privately owned housing units authorized by permit--Construction Reports, Bureau of the census

2. Public school enrollment for local educational agencies by residence for grades $\mathrm{K}-12$--Statistical Tables, R.I. Department of Education

3. Net residential expenditures for local educational agencies--Statistical Tables, R.I. Department of Education

4. Total debt service payments for local educational agencies--Statistical Tables, R.I. Department of Education

5. Municipal expenditures for public safety-Annual State Report on Local Government Finances and Tax Equalization, R.I. Department of Community Affairs

6. Full Assessed valuation contributed by the residential sector--Annual state Report on Local Government Finances and Tax Equalization, R.I. Department of Community Affairs

7. Annual mean of monthly convential mortgage rates--New England Economic Indicators, Federal Reserve Bank Boston

Originally, there was an effort to collect data on all school age children, (public, parochial, and independent). The reason that nonpublic enrollments were discontinued was that these enrollments were not broken down by residence prior to 1965. Also, there were no records of nonpublic school expenses to compare with the enrollment. The debt service payments for schools were added, since it would show the total municipal expense for local education. Also, if 
one were to track the debt payments one could determine when new school or additions were made, thus showing an increase of residential growth.

Municipal expenditures for public safety were used to indicate the commitment the local government had toward serving and protecting its residents. This data may be found in the local operating budgets, or in an annual report on local government finances.

The report in Rhode Island is titled the Annual State Report on Local Government Finances and Tax Equalization, compiled by the Rhode Island Department of Community Affairs.

The local crime index was identified to be used, but a lack of complete information and a revised definition of the index prevented its use. This information is often available through the local or state police department. But, in Rhode Island, uniform crime reporting only began in 1970 . The Federal Bureau of Investigation (FBI), collected information on crime indices for its annual Uniform Crime Report. The full title of the report is Crime in the United States. This report is not useful for this model because most municipal indices are aggregated together and not listed separately. The FBI does have a ten year back catalog of all of the crime indices that were reported, available on microfilm. This information is available by phone.

The information on the cost of housing is only available by state or listed by locality every ten years in the United States Census of Population and Housing. It was de- 
24

cided to use the full assessed valuation of personal property that was contributed by the residential sector instead. This also replaced the initial variable of equalized tax rate. These figures are available in the local operating budget or a state report on local finances. In Rhode Island, such a report is the Annual state Report on Local Government Finances and Tax Equalization published by the Rhode Island Department of Community Affairs. Careful attention must be paid to the valuation data. For instance, the 1979 annual report lists the land valuation for 1977 tax roll, which was based on the market value of the land in 1976. It is important to read the footnotes so that one can determine the actual market values. In order to determine the amount of personal property valuation that is contributed by the residential sector, a simple multiplication is made to the full assessed value as explained in equation (3).

Full Assessed Valuation Contributed by Residential Sector $=$ Full Assessed Value $\mathrm{x}$ Percent of Taxes Collected from the Residential Sector

The conventional mortgage rates that were used in this study are a mean of the twelve monthly rates collected for Boston, Massachusetts. The reason that Boston was chosen was that it was the only nearby city with the most complete data back to 1970 that was available. Between 1960 and 1969, a national average had to be used. More specific information is available at the Federal Reserve Banks. The Federal Reserve Bank in Boston needs special approval to release such 
25

information, because it necessitates a special computer run. Otherwise, in the New England area, the New England Economic Indicators, which began in 1969, contain area conventional mortgage rates which are published by the Federal Reserve Bank in Boston.

The last variable that was deleted due to a lack of information and inappropriate aggregation is per capita income. The problem with per capita income is that it is taken from the United States Census of Population and Housing, which is updated each decade, therefore, it cannot be used as an annual indicator.

This discussion concludes that data availability is the major factor in model design and a critical element in testing the model.

Methods of Calibration and Testing

Calibration will be done by the use of the statistical test of significance for the following statistics: F for the entire regression equation, $F$ for each independent variable which tests the ratio of the explained variance over the unexplained variance, therefore the higher the F statistic, the better the regression equation. The Durbin-Watson statistic will also use the test of significance. This statistic checks for autocorrelation which is the case when each residual (the difference between the actual dependent variable and the calculated dependent variable) is related 
by some arithmetic function. In simpler terms, the residuals are related, which can cause inappropriate results. This happens when the regression equation is not linear, but a polynomial (quadratic, cubic, quartic, etc.) or, when an additional and important independent variable is missing. The optimum Durbin-Watson statistic has a value of 2.0 .

The other general statistics which help to calibrate the model are the correlation coefficient " $r$ " and the coefficient of determination " $r$ ". By maximizing these coefficients, one will yield the best regression equation, while the standard error of the estimate should be minimized. The testing prodedure is as follows:

1. run the SPSS regression subprogram with all of the independent variables.

2. note all of the pertinent statistics

3. locate the lowest $F$ statistic for the variable in the equation. Then remove that variable from the regression equation.

4. run the SPSS regression subprogram

5. repeat steps 2, 3, and 4 until the F statistic for this entire regression equation is maximized while the standard error is minimized and Durbin-Watson statistic is close to a ratio of 2.0 . After running all combinations of independent variables, if not one of the regression results is acceptable statistically, then the model does not apply. 6. In order to determine the best regression equation, 
one should insert variables that have been previously removed to form new combinations of variables which have not yet been tried.

\section{Summary}

By answering the questions set up by $A$. G. Wilson (see table $(I-1)$, as presented above, the major steps and procedures have been identified and explained.

A few key points should be remembered. One is that one's hypothesis may not always be proven true. Another key point is the limitations that the availability of data can have on the development of a model. Finally, one must realize that the final model must make logical sense in terms of the affects that the independent variables have toward the dependent variable. 
${ }^{\text {I }}$. G. Wilson, Urban and Regional Models in Georgaphy and Planning, (Bristol, England: John Wiley \& Sons, Itd., 1974), p. 3I.

2 Joe-On Kim et al., "Multiple Regression Analysis:

Subprogram Regression," Statistical Package For the Social Sciences Manual, 2nd ed. (New York: McGraw-Hill Book Company, 1975), pp. 320-360.

${ }^{3}$ Earl Finkler et al., Nongrowth Planning Strategies: The Developing Power of Towns, Cities and Regions, (New York: Praeger Publishers, 1974), pp. 91-100. 
CHAPTER III 
User's Manual

Assumptions

The basic assumptions behind this study are: (1) new housing building permits are an indication of the localities' residential growth; (2) public school enrollment, public school expenditures, public school debt service payments, full assessed value of residential property and conventional mortgage rates are related in a linear fashion to the localities' residential growth.

These assumptions structure the list of factors (variables) which determine the number of new building permits issued for the next year.

This determination is accomplished through a multiple regression analysis. The regression coefficients show the actual magnitude and direction of influence that each significant independent variable has toward the dependent variable (new building permits).

The goal of this study is not to determine a general equation that applies to all localities. Instead, it at30 
tempts to set up a general procedure for local planning agencies to produce their own specific and unique growth equation. The independent variables that were chosen initially are by no means exhaustive, (this will be discussed in the "Limitations" section of this chapter) but are a representative list which represent a starting point for most agencies.

All previous discussions have focused on the residential growth of a locality. Residential growth infers an increase in the number of housing units and people living in the area. The reason that growth is discussed, is that it is assumed that nongrowth is a reaction to over growth. When growth is understood and numerically explained, then one can begin to understand and explain nongrowth.

\section{Application}

The development of this model included the objective of creating a replicable model which applies to any locality in the United States. It is Iimited to the United States since other nations have different tax structures and educational systems.

The use of this model on a broader scale than originally developed for is also possible. A regional or state model could be developed because more data of a higher quality is available at that level of aggregation. However, the interpretation of such a model becomes very complicated. For 
example, if one major town in a region changed its property tax policy in such a way as to increase the full assessed value of that property, this may result in a dramatic increase in the predicted growth. The problem is in determining where the actual growth will occur, and where policy changes result in predicted growth (which may not be actual growth) .

This model can be used when a locality has a need to determine what will be the realized growth of the next year and in broader terms, what the major indications are of that growth. This study was set up to specifically evaluate the influences of nongrowth planning strategies through the assessment of indirect change of certain growth indicators. This study looks at the projected growth indicators and the independent variables for one year ahead and applies them to the growth equation which results in a predicted growth for the next year. The determination of the values of the growth indicator must consider all of the communities' growth and/or nongrowth policies that will influence these indicators. The actions of nongrowth policies are thus reflected in the growth equation in an indirect but meaningful manner.

Uses of Model

When a locality decides to compare the differences in building permits resulting from present growth policies with the results of future nongrowth policies, it must fol- 
low these procedures: (1) determine the present and future values of all significant growth indicators; (2) run a regression equation with these values which determine a predicted number of new building permits to be issued; (3) replace the future value of the significant growth indicator with values that will result when nongrowth policies will be in effect; (4) make a second run of the regression equation using the new future data; (5) compare the two different predicted amounts of new building permits.

This model was developed for the use of any locality who wished to develop its own growth equation. Nonetheless, there are some limitations which will be discussed in the next section.

\section{Limitations}

In the development of a general concept applied to specific locations, unique cases which do not fit the stated assumptions exist.

A case in point is when the majority of the independent variables do not explain the dependent variable. This can be recognized when all of the $F$ statistics for each individual independent variable are insignificant, (test of significance is described in the "Statistical Analysis" section of this chapter) as well as the F statistic for the entire equation. It is important to try all possible combinations of variables before making such a determination. 
This model is currently limited to a maximum of six independent variables. This limitation is the result of the decision to only use data which is widely available to most planners. At the same time the data must represent appropriate indicators of residential growth.

Implicit in this model is that the model does not directly evaluate the effects of nongrowth policies. All of the nongrowth effects are done outside the model and the resulting variable changes are entered into the model. This is because the three cases in this study have instituted some informal nongrowth policies within the last year. For example, North Kingstown has instituted interim zoning, until revised and formal growth policies can be developed.

\section{Alternative Method}

If the situation exists where a locality has instituted a formal growth policy at least five to six years prior to a nongrowth study, then a different evaluation method may be used. This would entail the use of a "dummy variable" in the regression equation. The steps for the alternative method are as follows: (I) A value of one (I) would be used for each year that the limited growth policy was in effect for the dummy variable; (2) For all the years that it was not in effect, a value of zero (0) should be used; (3) Subsequent to this the same procedure listed in the "Technique" section of chapter II should be followed; 
(4) Test the significance of the dummy variable by using its F statistic, if it is significant then the regression coefficient (B) will explain how it affects the residential growth of an area.

It is very important to realize that there must be a sufficient number of years prior to the actual testing. (A good rule would be a minimum of one quarter of the entire study period).

\section{Findings}

This study finds that the methods described in the "Technique" section of chapter II can produce a specific growth equation for a locality.

\section{South Kingstown}

South Kingstown, Rhode Island used the greatest number of independent variables in its equation. The new residential building permits were described positively by the full assessed evaluation of residential property, the public school expenditures, and the public school debt service payments. Negative indications came from public school enrollment and public safety expense (see table A-7, page 3). The actual equation for South Kingstown is shown in equation (1). 


$$
\begin{aligned}
\text { BUILDPER }= & 0.514(\text { ASSESSVA })-0.162(\text { SCHLENOL }) \\
& +0.047(\text { SCHOOLEX })+0.254(\text { SCHLDEBT }) \\
& -0.126(\text { SAFETYEX })+428.9
\end{aligned}
$$

The only problem statistically is whether to use public school debt service payments. The minimum F statistic for debt service should be at least $1.761 \quad(d f=14,=0.05)$ (see table A-II) but the actual F statistic is 1.273. Another run was made dropping debt service from the equation. However, this lowered the $F$ statistic for the entire equation from 9.785 to 7.081 , so debt payments were reinserted into the regression equation. The Durbin-Watson statistic is also an acceptable value of 2.028 (see table A-12)

North Kingstown

North Kingstown, Rhode Island has the highest F statistic for the entire equation, which is 17.045 . But only half of the independent variables were found to be significant. Nonetheless, those that were significant were so to a very high degree.

The only questionable statistic in the case of North Kingstown is the test for autocorrelation, using the DurbinWatson statistic. This statistic has a value, in North Kingstown's case, of 1.286. According to table $A-12,(n=16$, $\mathrm{k}=3$ ) this statistic should be above the upper limit which is 1.73. Instead, it is between the upper (1.73) and the lower $(0.86)$ values which mean that the test is inconclusive 
(see graph in table A-12). There may be some nonlinear expression that will explain the relationship between the dependent variable and independent variables in a better fashion. The actual equation used for North Kingstown is shown below in equation (2) and table A-8, page 3 .

$$
\begin{aligned}
\text { BUILDPER }= & -1.208(\text { ASSESSVA })-0.017(\text { SCHOOLEX }) \\
& +0.302(\text { SCHLDEBT })+228.90
\end{aligned}
$$

Jamestown

The Town of Jamestown, Rhode Island is a case where the model did not apply. The F statistic for the entire equation was only 2.283 instead of being greater than 3.59 ( $d f=2, d f_{2}=17$ ) in table $A-11$. This means that more of the varience of the entire equation is left unexplained than explained, therefore, the equation is not valid.

The unapplicability of this case is explained in the "Limitations" section of this chapter, which is that the independent variables increased annually while the new residential permits (dependent variable) remained constant, around a mean of 42. Simply, the independent variables did not explain the dependent variable.

\section{Summary}

In summary, all three different towns showed different levels of reliability in using the model presented in this 
study. It should also be noted that although some variables were contained in two different town models, none were contained in all three. Further, these common variables affected the dependent variable in entirely different manners. For example, in South Kingstown, the assessed valuation affected the new building permit by -1.207 , while in North Kingstown the factor is +0.514 , and in Jamestown it was insignificant.

From this one can conclude that the concept of determining a locality's future growth due to specific policies by the methods presented in this study is valid. However, each locality must modify the general equation and determine its own separate and unique equation and reasoning to justify the use of each variable.

\author{
Explaination of Algorithm
}

An algorithm is a procedure in order to solve a problern in a finite amount of steps. The algorithm for this model is expressed in graphic forms as a system flow chart as seen in table III-l.

The first step is to read in the annual data for a specified study period. Then this data is used as input to the SPSS regression subprogram. The regression analysis is broken down into six major steps which are listed on the right of table III-I. The method of "least squares" is used to determine the regression coefficients. 


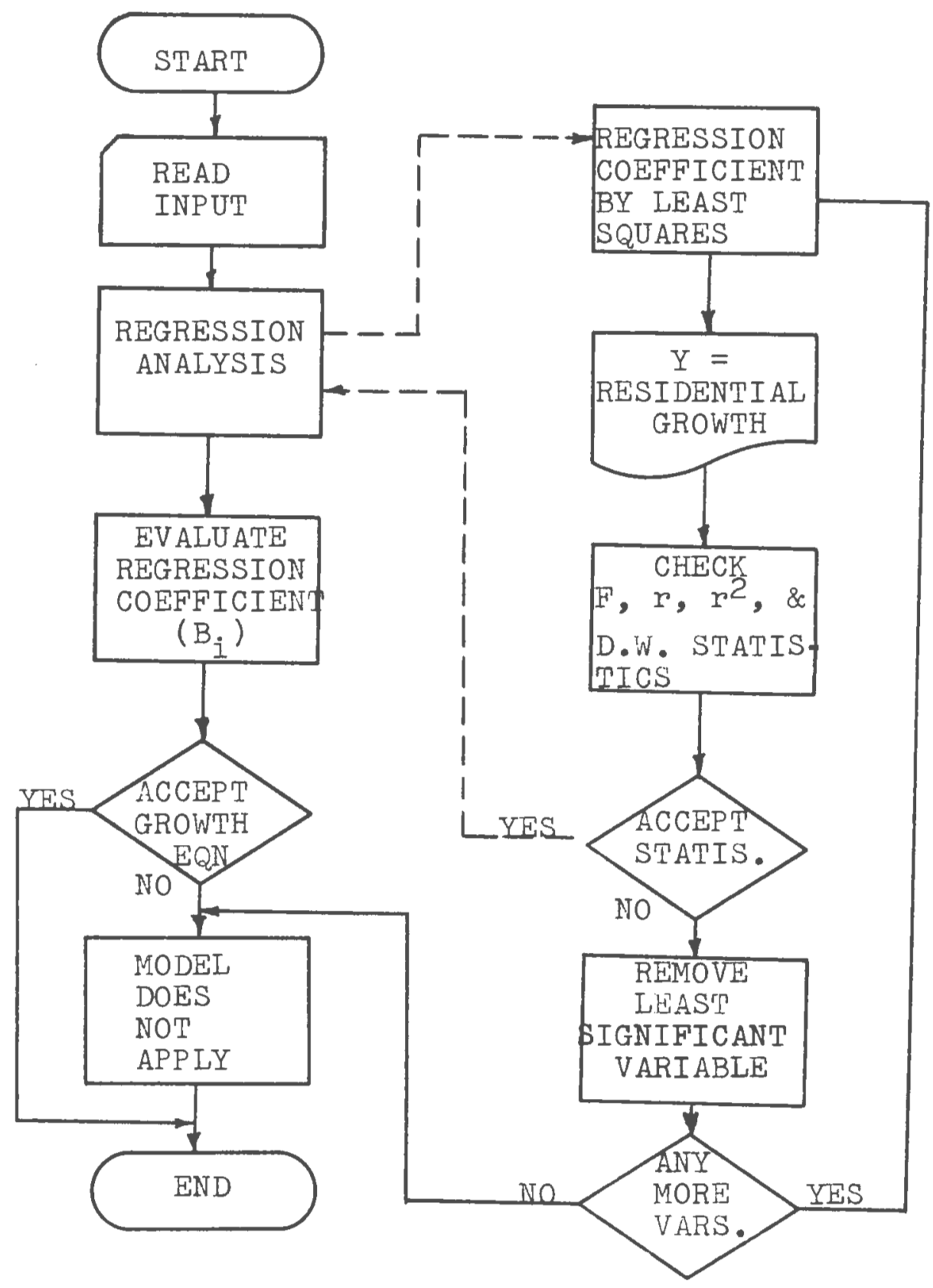


40

The regression equation, which explains residential growth is then printed out. A good check of the listed statistics must be performed after each run. If the statistics are acceptable then the regression segment of the algorithm is complete. If there are insignificant variables still remaining in the equation, then the least significant variable should be removed and new coefficients should be calculated. This process should be repeated until an acceptable equation is created or all combinations of variables have been tried, in which case the model does not apply.

Once the regression analysis is completed, the coefficients must be evaluated. If the equation is accepted as a means to approximate the next years' residential growth, then the algorithm ends, and final conclusions can be made. However, if the model does not apply, then it must be determined, whether it was incorrect data or whether the model cannot explain those sets of circumstances that have led to that specific localities' growth (or nongrowth).

Input Data

The data that is used for input for this study is listed in tables $A-1$ through $A-6$, in the appendix. It is listed there by subject heading, however, to be used by SPSS regression it must be by locality. The format for the SPSS input data is described in the SPSS User's Manual ${ }^{I}$ in chapter four. An example of the final outcome is listed in 
table A-7, page 1.

All input data should be at the same level of aggregation and time sequence. This means that each run must represent one specific locality and should be all annual, or monthly, or some other convient time period that all data is available. (Statistically, it is better if the smallest amount of time could be used).

Missing Data

If there is missing data the following guides should be used. If one or two non-contiguous data points are missing a simple linear interpolation is allowed. If more than two data points are missing, then leave them blank. The SPSS regression package will assign appropriate values consistant with the available data. However, it will not use any data from the same time period as the missing data when calculating all of its statistics.

All other details should follow the examples listed in the appendix (see tables A-7 through A-9). For an explanation, see the "Regression Subprogram" chapter in the SPSS Manual. 2

How to Run the Program

Once the data and the input format are set up, the program must be run. Appendix $\mathrm{F}^{3}$ in the SPSS Manual has a 
42

good description of the basic steps to run any SPSS package, however, most computer facilities have modified and simplified these procedures. Therefore, the first step would be to check with the user service group at the computer installation where you will be performing the SPSS runs. Remember that almost every installation has different procedures for the same packages.

What To Look For in the Output

The signals to look for first are error messages. These messages may not be very helpful or lead you to the cause of the problem, therefore one should consult an SPSS expert.

The next area of difficulty is in the statistical interpretation, to determine what is significant and what is not. This will be discussed in the next section. The rest of what to look for is rather simple. First, make sure that what has been set up as the SPSS program is actually what the computer read. Incorrect information in the SPSS program may greatly misinterpret your data. It cannot be emphasized enough how important it is to make sure that one's input data is being read from the correct columns and that the decimal place (if any) is also correctly located.

If a statistic has a value of all nines (9999.99), tren it could not be calculated. This is a signal to the user 
that there is a mistake and one should rerun the input data and the input format.

\section{Statistical Analysis}

In order to understand the following discussion, one must be familiar with basic statistical concepts, such as hypothesis testing, in particular, the test of significance 4 and regression analysis.

The first statistic listed (see table A-7, page 2) is the correlation coefficient $r$. This explains how well the independent variables are correlated to the dependent variable. It has a value between zero and one, one being perfectly correlated.

The coefficient of determination, $r^{2}$, measures the ratio of the explained sum of squares to the total sum of squares. It indicates the proportion of the total variation in variable $Y$ (dependent variable) that is explained by its linear relationship with $X$ (independent variable). It also has values between zero and one.

In SPSS, the regression coefficients are labeled as B. The significance test for $B$ is by evaluating the F ratio. By using the F value (see table A-7, page 2) with degrees of freedom in the numerator $\left(\mathrm{df}_{1}\right)$ called regression degrees of freedom and degrees of freedom in the denominator $\left(\mathrm{df}_{2}\right)$ called residual degrees of freedom, one can locate the minimum value of the F ratio. Compare this table value to the 
calculated, if the calculated is equal or greater than the coefficient $B$ is significant. Note, if there are less than thirty data points than the table value should be located in the student's T-table (see table A-10).

The other important statistic for this model is the Durbin-Watson statistic. This statistic checks the relationship of the residuals. A plot of the standardized residuals is located in table A-7, page 5).

TABLE III-2

RESIDUAL PATTERNS

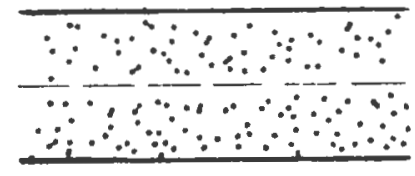

(a)

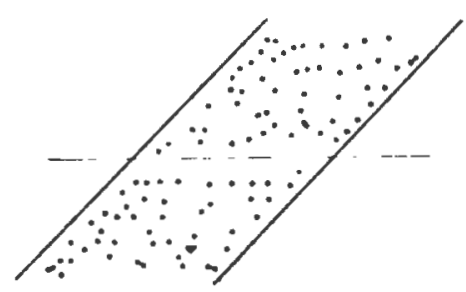

(c)

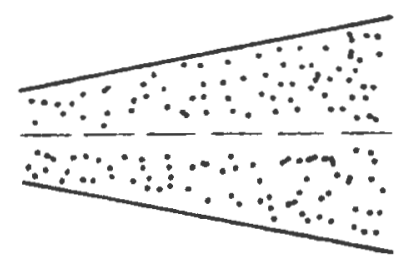

(b)

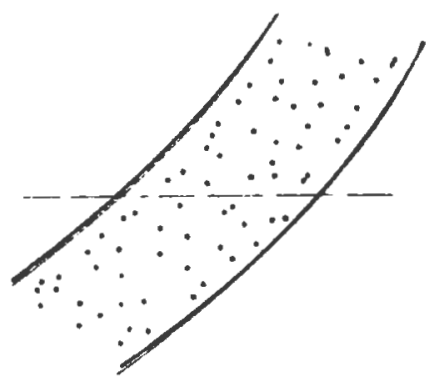

(d)

If, for example, all of the residuals were clustered in a linear pattern like (c) in table III-2 above, then this would indicate a lineer relationship between residuals and the variable on the horizontal axis. Other patterns which 
may occur are shown in (b) and (d). Pattern (a) shows relative freedom from abnormalities, when this occurs the DurbinWatson has a value close to 2.0. For acceptable values, use table $A-12$.

If the Durbin-Watson statistic is at an unacceptable level, then the assumption of a linear relationship between the independent and dependent variables is false. Complete treatment of residual analysis is provided by $N$. Draper and H. Smith $(1966)^{5}$. The previous discussion of the residual analysis was condensed from the SPSS Manual ${ }^{6}$.

\section{How To Use the Results}

This final section will summarize how to take the regression equation and apply it to a growth or nongrowth policy analysis.

As explained in the "Application" section of this chapter, the input of the regression equation reflects all growth or nongrowth policies in effect during the study period. Therefore, most of the analysis of the policy changes will already have been performed. This model will take all changes into account and then calculate a resulting indicator of residential growth (new residential building permits).

When evaluating the regression coefficients, one should take interest in the sign of each coefficient. Using North Kingstown for example, (see equation 3) the coefficients for 
46

assessed valuation is -1.207 . This means that when there is an increase in the assessed valuation of residential property in North Kingstown the number of new residential building permits will decrease by 1.207 times the total new dollar amount of assessed valuation. An increased in public school debt service payments, will result in an increase in the number of new building permits by 0.302 times the new debt service payment.

As a last note, valid predictions are only for one year ahead. This is due to the large fluctuation in the different political and economic arenas of today. If there are any major changes that affect one's independent variables, whether used or not, a new model must be run.

\section{Summary}

The ability for small and mid-size planning agencies to help evaluate the results of limited or nongrowth policies in a simple fashion has been the goal behind this study.

The goal has been reached through the use of the model developed in this study. In a period of ten to eleven weeks a planner should be able to collect six different growth indicators, set up the model, run the regression, and evaluate the output.

The important limitations of this study are the problems with data availability and aggregation, and whether 
47

the chosen indicators do indeed have a linear relation to the locality's growth. Another important point is that the input data (the independent variables) must reflect any changes in growth policies. This model will not calculate the changes occuring for each growth indicator, but will only evaluate the effect that each growth indicator has towards growth when taken together. Finally, after developing a statistically acceptable growth model, one must be confident that the model makes logical sense. This is because many variables can be related, but this does not mean that one can predict the other. 


\section{8}

FOOTNOTES

Chapter III

$I_{\text {Norman }}$. Nie et al., Statistical Package For the Social Sciences Manual, 2nd ed. (New York: McGraw-Hill Book Company, 1975), pp. 35-64.

Ibid., pp. 320-367.

3.bid., pp. 585-603

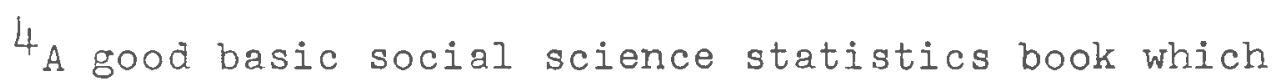
reviews these concepts is Simon $W$. Tai, Social Science Statistics: Its Elements and Applications, (Santa Monica: Goodyear Publisher, 1978).

${ }^{5}$ N. R. Draper and H. Smith, Applied Regression Analysis, (New York: Wiley, 1966). 6 Norman H. Nie et al., Statistical Packase For the Social Sciences Manual, 2nd ed. (New York: McGraw-Hill Book Company, 1975), pp. 341-342. 
APPENDIX 
Municipality

Year Jamestown North Kingstown South Kingstown

$\begin{array}{llrr}1960 & 35 & 102 & 83 \\ 1961 & 28 & 153 & 74 \\ 1962 & 27 & 139 & 88 \\ 1963 & 31 & 156 & 92 \\ 1964 & 34 & 238 & 139 \\ 1965 & 42 & 245 & 106 \\ 1966 & 33 & 182 & 75 \\ 1967 & 29 & 198 & 69 \\ 1968 & 80 & 160 & 124 \\ 1969 & 36 & 163 & 73 \\ 1970 & 35 & 197 & 93 \\ 1971 & 42 & 346 & 159 \\ 1972 & 84 & 200 & 236 \\ 1973 & 69 & 102 & 181 \\ 1974 & 31 & 88 & 126 \\ 1975 & 28 & 81 & 190 \\ 1976 & 39 & 108 & 265 \\ 1977 & 36 & 371 & 115 \\ 1978 & 59 & 316 & 262^{\mathrm{a}} \\ 1979 & 32 \mathrm{~b} & 282 & 409\end{array}$

SOURCE: U.S. Department of Commerce, Bureau of the Census, Construction Reports, C - 40 Series, Table No. 4.

actual figure not available, therefore a linear interpolation was made.

bonly nine (9) months of data was collected, therefore the actual figure of 24 new permits was adjusted for twelve months, thus yielding 32 new permits for the year. 


\section{1}

TABIE A-2

PUBLIC SCHOOL ENROILIENT FOR IOCAI ELUCATICNAL AGENCY BY RESIEENCE

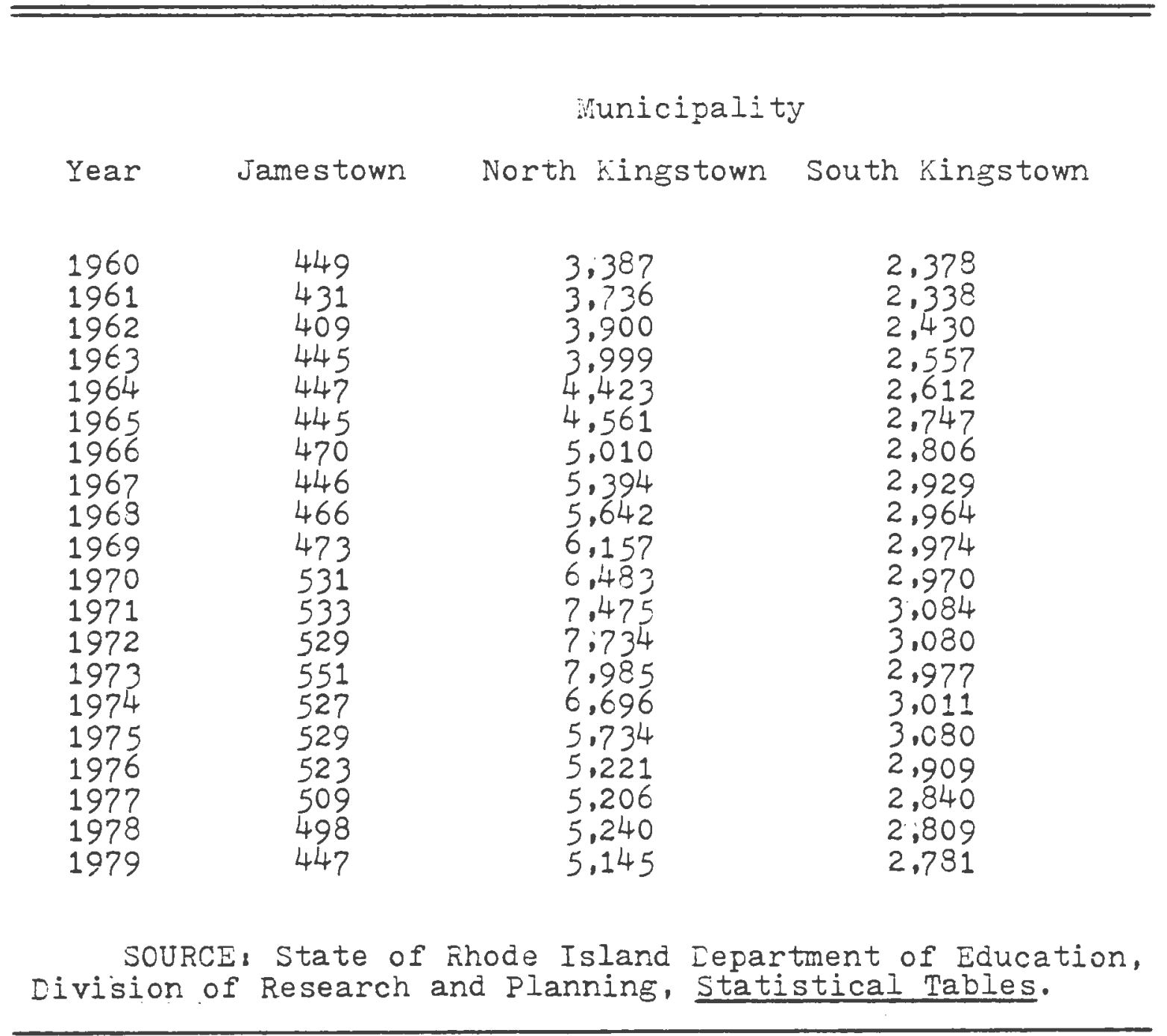


TABLE A-3

NET RESIDENTIAI EXPENDITURES FOF IOCAI ELUCATICNAI AGENCIES (Woney Amounts in Thousands of Dollars)

\begin{tabular}{lccc}
\multicolumn{4}{c}{ Municipality } \\
Year & Jamestown & North ringstown & South ring \\
& & & \\
1960 & 197 & $1,1,7$ & 687 \\
1961 & 212 & 1,284 & 794 \\
1962 & 233 & 1,451 & 841 \\
1963 & 261 & 1,683 & 967 \\
1964 & 281 & 1,855 & 1,080 \\
1965 & 257 & 1,984 & 1,244 \\
1966 & 324 & 2,247 & 1,417 \\
1967 & 312 & 2,684 & 1,662 \\
1968 & 356 & 3,075 & 1,887 \\
1969 & 381 & 3,739 & 2,270 \\
1970 & 446 & 4,388 & 2,476 \\
1971 & 549 & 5,045 & 2,686 \\
1972 & 635 & 5,851 & 3,073 \\
1973 & 727 & 6,696 & 3,523 \\
1974 & 763 & 6,869 & 3,767 \\
1975 & 848 & 6,756 & 4,329 \\
1976 & 888 & 6,665 & 4,888 \\
$197 ?$ & 1,003 & 7,373 & 5,361 \\
1978 & 1,092 & 7,329 & 5,803 \\
1979 & 1,153 & 8,612 & 6,486
\end{tabular}

SOURCE: State of Rhode Island Eepartment of Education, Division of Résearch and Flanning. Statistical Tables.

NOTE: Residential Expenditures is the cost to run the Local Educational Agencies after all non-resident tuition and expenses have been removed. State and Federal contributions are included. 
53

TABIE A-4

TOTAL LEBT SERVICE PAYVENTS FOR IOCAI ELUCATIONAI AGENCIES (ivoney Amounts in Thousands of Dollars)

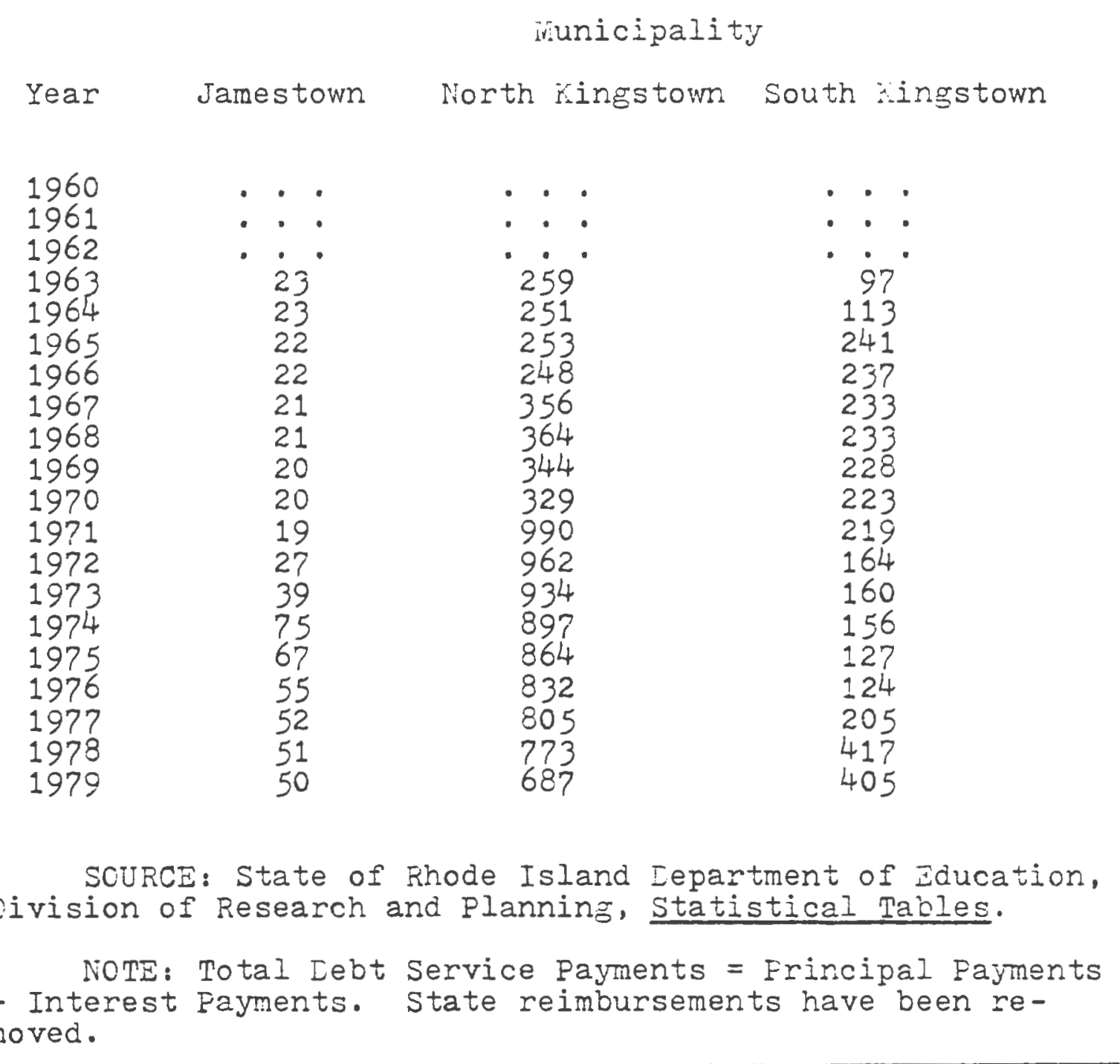


54

TABII A-5

MUNICIFAI EXFENDITUEIS FOR FUBIIC SAFETY

(Money Amounts in Thousands of Lollars)

\begin{tabular}{|c|c|c|c|}
\hline \multirow[b]{2}{*}{ Year } & \multicolumn{3}{|c|}{ Municipality } \\
\hline & Jamestown & North Kingstown & South ringstown \\
\hline $\begin{array}{l}1960^{\mathrm{a}} \\
1961 \\
1962 \\
1963 \\
1964 \\
1965 \\
1966 \\
1967 \\
1968 \\
1969 \\
1970 \\
1971 \\
1972 \\
1973 \\
1974 \\
1975 \\
1976 \\
1977 \\
1978 \\
1979^{a}\end{array}$ & $\begin{array}{r}37 \\
42 \\
47 \\
50 \\
52 \\
58 \\
59 \\
66 \\
80 \\
94 \\
107 \\
131 \\
137 \\
148 \\
174 \\
200 \\
206 \\
233 \\
248 \\
269\end{array}$ & $\begin{array}{r}154 \\
191 \\
247 \\
265 \\
280 \\
312 \\
394 \\
396 \\
462 \\
557 \\
623 \\
677 \\
807 \\
861 \\
1,039 \\
1,196 \\
1,288 \\
1,424 \\
1,559 \\
1,695\end{array}$ & $\begin{array}{l}95 \\
117 \\
140 \\
138 \\
174 \\
190 \\
212 \\
218 \\
245 \\
275 \\
318 \\
389 \\
433 \\
463 \\
513 \\
653 \\
769 \\
814 \\
898 \\
963\end{array}$ \\
\hline sot & $\begin{array}{l}\text { State of } \\
\text { nual State } \\
\text { alization. }\end{array}$ & $\begin{array}{l}\text { Rhode Island Depar } \\
\text { Report on Iocal Go }\end{array}$ & $\begin{array}{l}\text { tment of Communit } \\
\text { vernment Finances }\end{array}$ \\
\hline
\end{tabular}


FULI ASSESSED VAIUATION CONTRIBUTED BY RESIDENTIAL CIASS (rioney Amounts in ilillions of Dollars)

\begin{tabular}{|c|c|c|c|}
\hline \multirow[b]{2}{*}{ Year } & \multicolumn{3}{|c|}{ Nunicipality } \\
\hline & Jamestown & liorth Kingstown & South Kin \\
\hline $\begin{array}{l}1960 \\
1961 \\
1962 \\
1963 \\
1964 \\
1965 \\
1966 \\
1967 \\
1968 \\
1969 \\
1970 \\
1971 \\
1972 \\
1973 \\
1974 \\
1975 \\
1976\end{array}$ & $\begin{array}{l}13.9 \\
15.5 \\
15.5 \\
16.2 \\
17.3 \\
18.7 \\
20.9 \\
22.2 \\
23.9 \\
26.3 \\
31.9 \\
35.8 \\
52.3 \\
71.5 \\
76.0 \\
82.1 \\
87.7\end{array}$ & $\begin{array}{r}28.4 \\
46.6 \\
47.2 \\
51.8 \\
64.9 \\
61.7 \\
69.0 \\
81.7 \\
87.5 \\
104.8 \\
118.3 \\
128.1 \\
164.5 \\
188.7 \\
216.2 \\
235.6 \\
240.4\end{array}$ & $\begin{array}{l}23.5 \\
43.7 \\
43.5 \\
43.8 \\
45.9 \\
50.5 \\
54.9 \\
60.9 \\
73.0 \\
88.3 \\
99.1 \\
114.4 \\
130.7 \\
164.5 \\
187.3 \\
201.0 \\
240.4\end{array}$ \\
\hline $197 ?$ & . . . & - . & - . . \\
\hline 1978 & . . . & . $\cdot$. & . $\cdot$ \\
\hline 1979 & . . . & . . . &.$\quad$. \\
\hline
\end{tabular}

SOURCE: State of Rhode Island Eepartment of Community Affairs, Annual State Report on Local Government Finances and Tax Equalization.

NOTE: Full Assessed Valuation by Residertial Class is the percent of Total Tax on Feal and Tangible Froperty Contributed by Residential Class applied to the Fuil Assessed Value. The Full Assessed Value is based on the previous year's market value.

'1973's data was adjusted in the 1976 Annual Report. 


\section{TABLE A-7 \\ SOUTH KINGSTOWN}

SPSS BATCF STSTER

3er29ren Pace,

SPSS POP OS/360. TEASTON M. RELESE 0.0 , OCTOBER 15, 1979

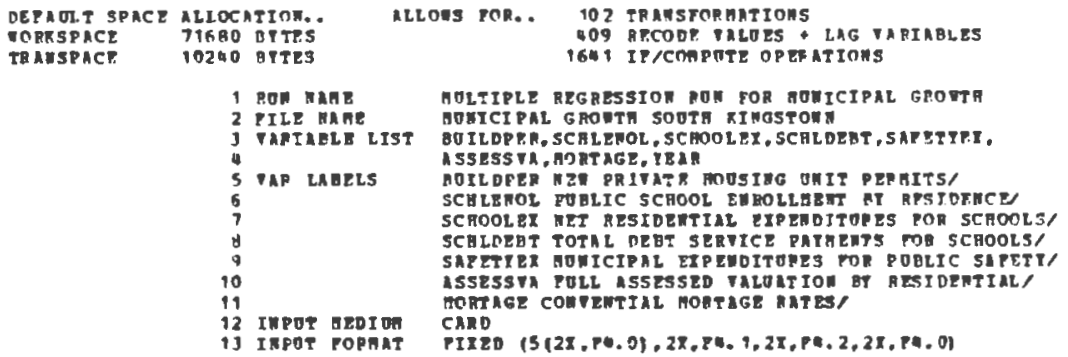

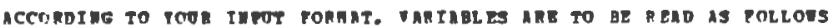

\begin{tabular}{|c|c|c|c|c|}
\hline TREIABLE & PORMAT & RECORD & COLOH & ans \\
\hline OUILDPEB & P. 0 & I & 3- & \\
\hline SCHLENOL & $\because 0$ & 1 & 9 & 12 \\
\hline SCROOLET & $\because \cdots 0$ & $i$ & 15. & 18 \\
\hline SCALDEQT & $\because 1.0$ & 1 & $21-$ & 24 \\
\hline SAPETTEX & $\because \because 0$ & i & $27-$ & 30 \\
\hline issess if & P. 1 & i & $33=$ & 36 \\
\hline BORTACB & 10.2 & $i$ & $39=$ & 2 \\
\hline TEAP & $P$ & 1 & is- & 90 \\
\hline
\end{tabular}

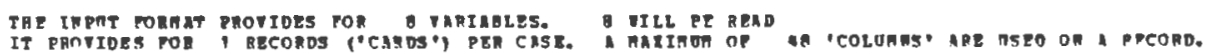

IT PANTIDES rog

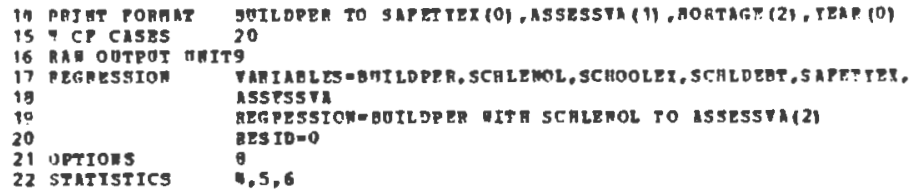

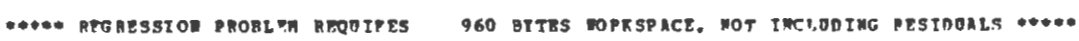

23 ARAD IMPOT DATA

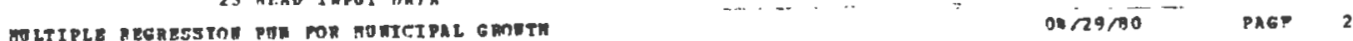

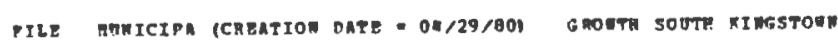

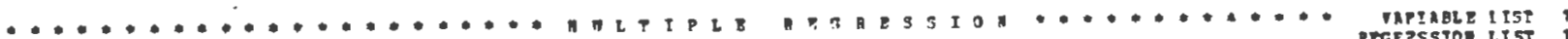

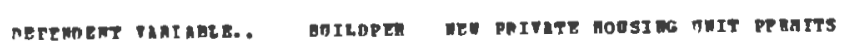

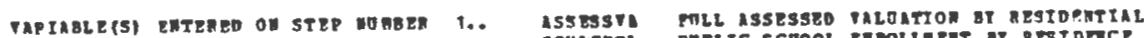

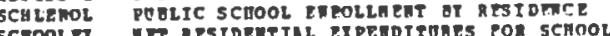

SCHOOLEX MET MESIDENTIAL EXPEDDTYOAES POR SCHDOLS

SCHLDER TOTAL DEDT SERTICE PNTHEMTS POA SCROOLS

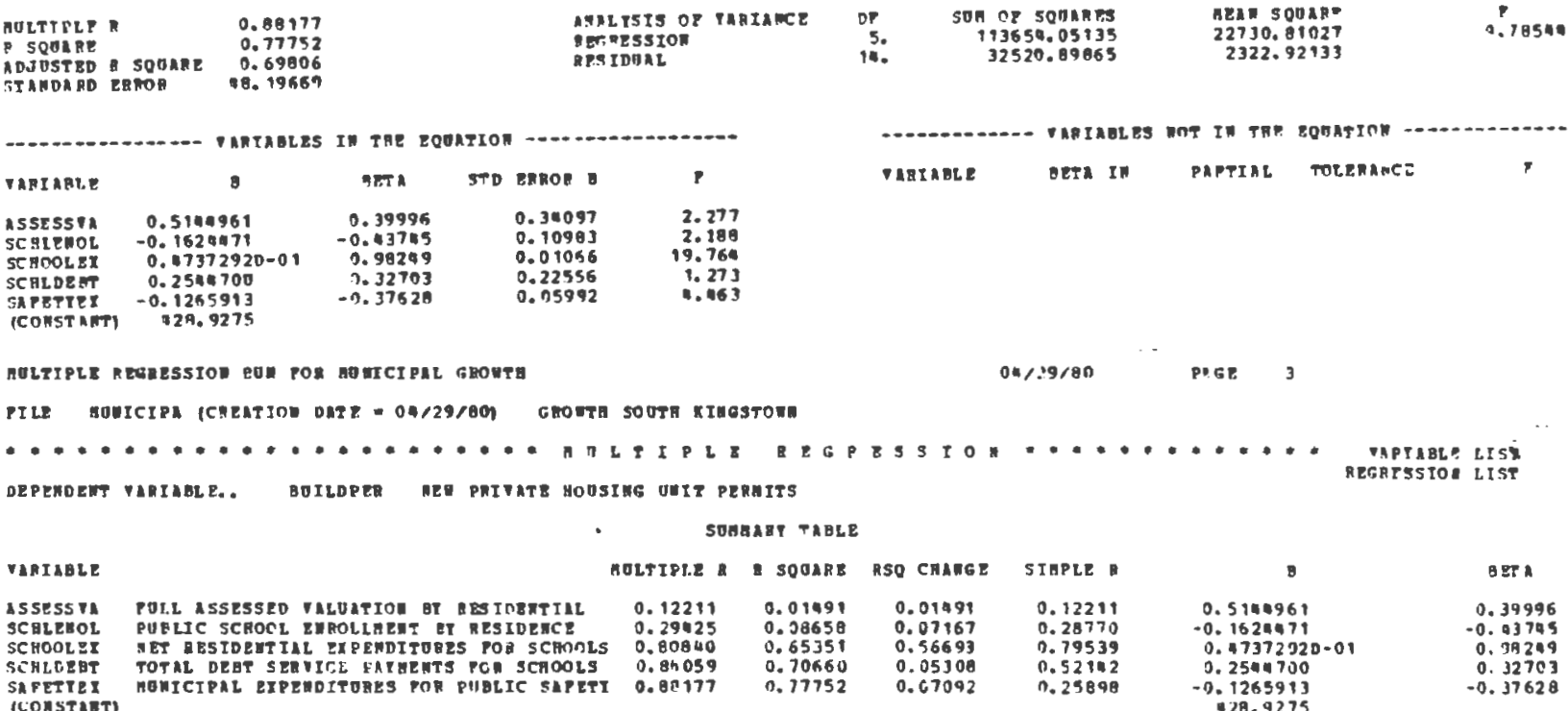




\section{TABLE A-7 (CONTINOED)}

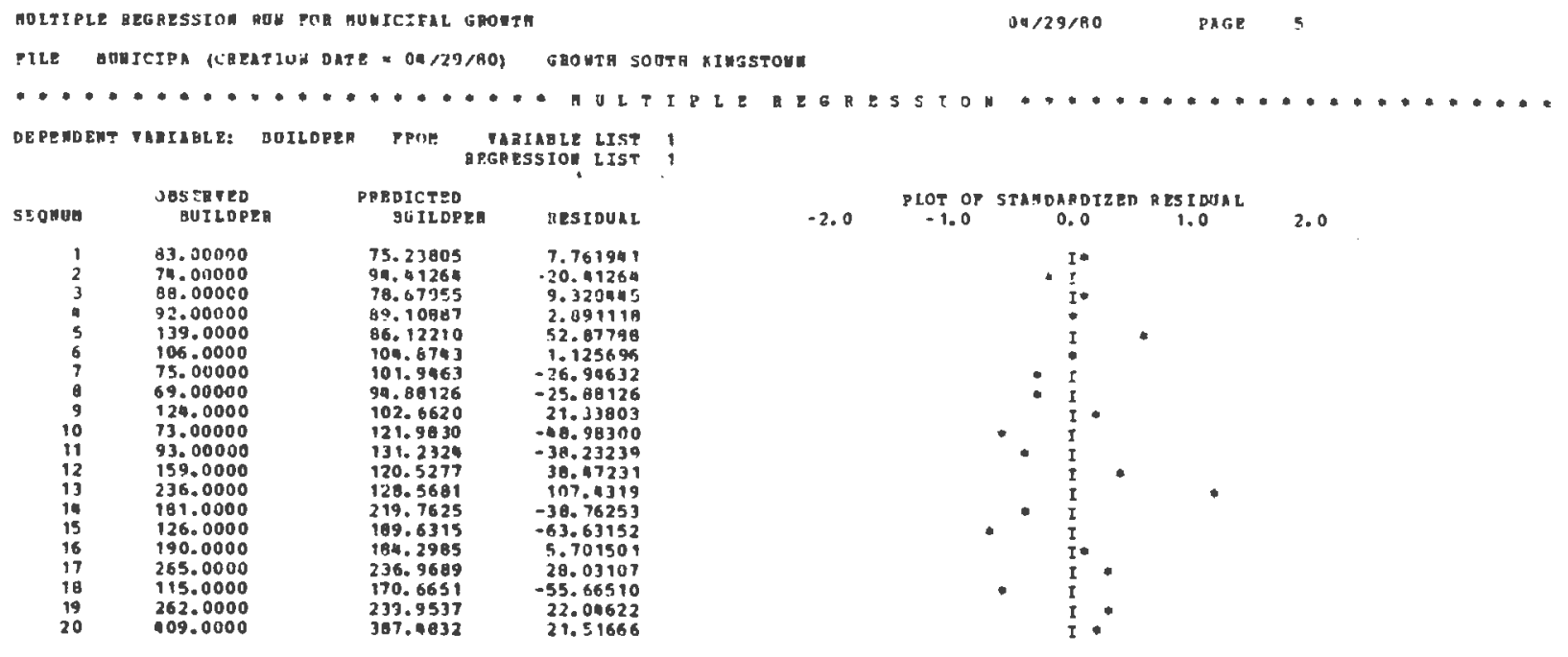

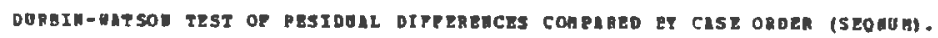

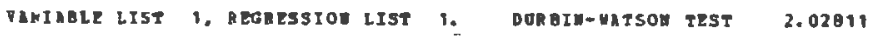

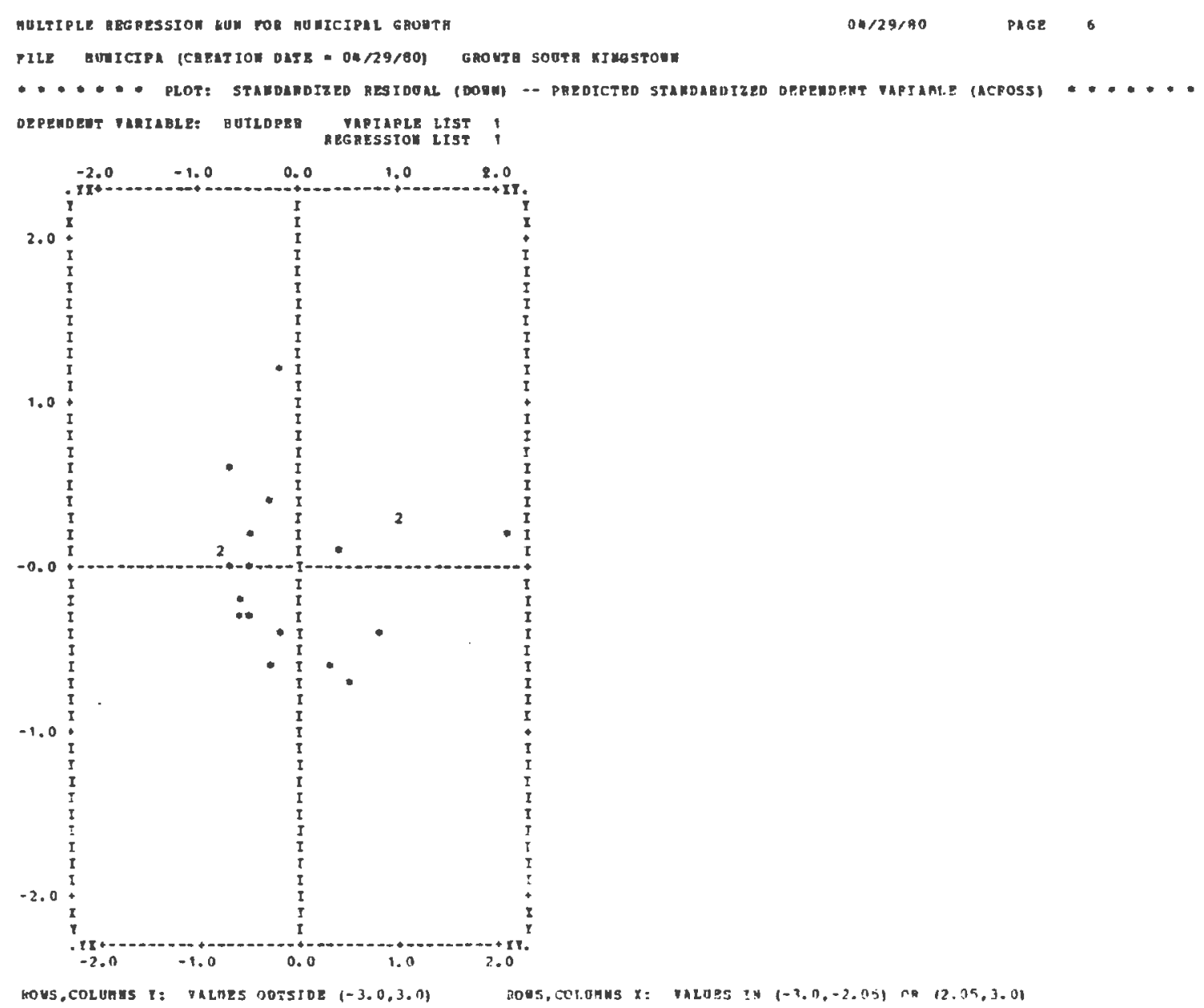




\section{TABLE A-8 \\ NORTH KINGSTOWN}

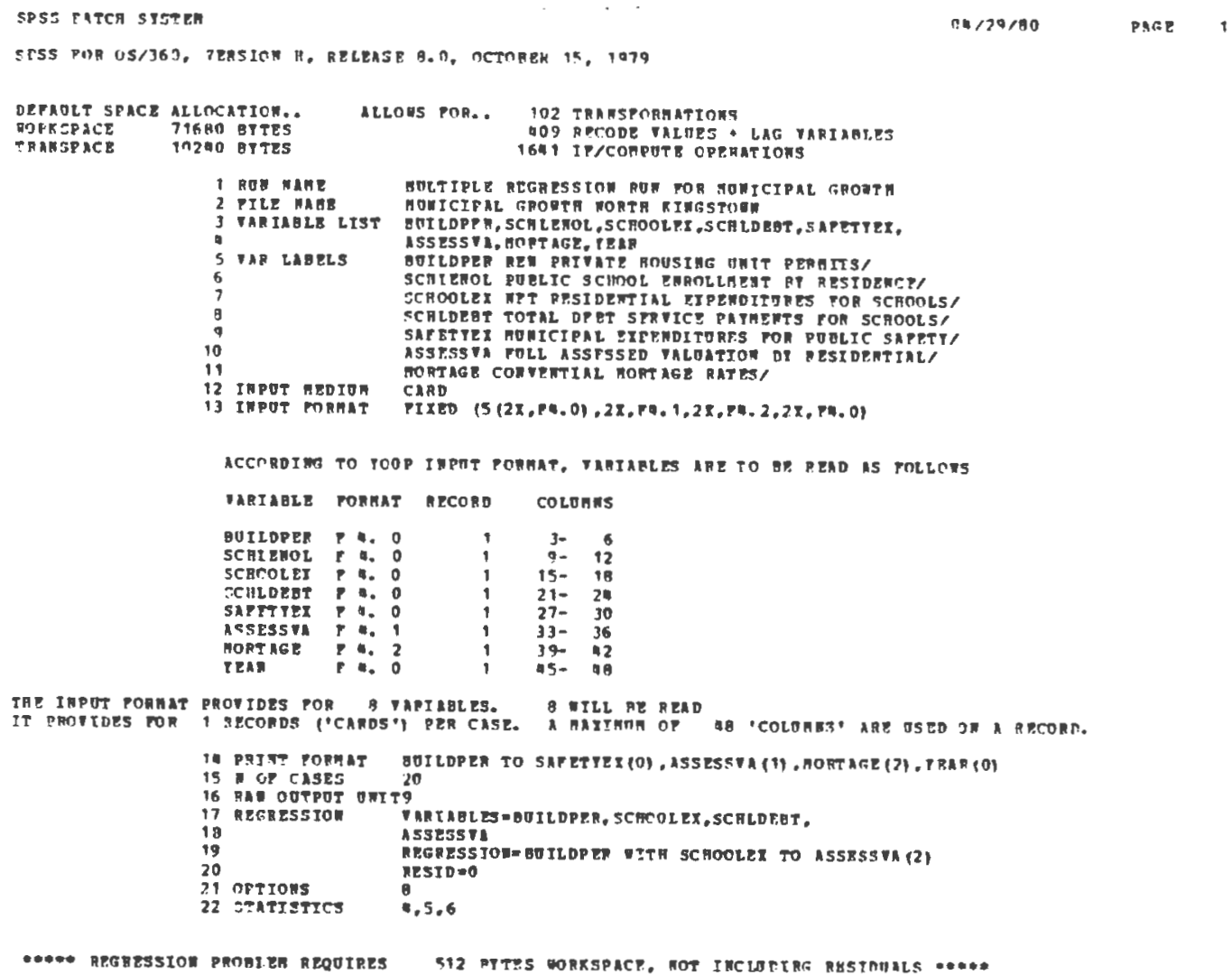

23 Bgar IEPTI DAS-

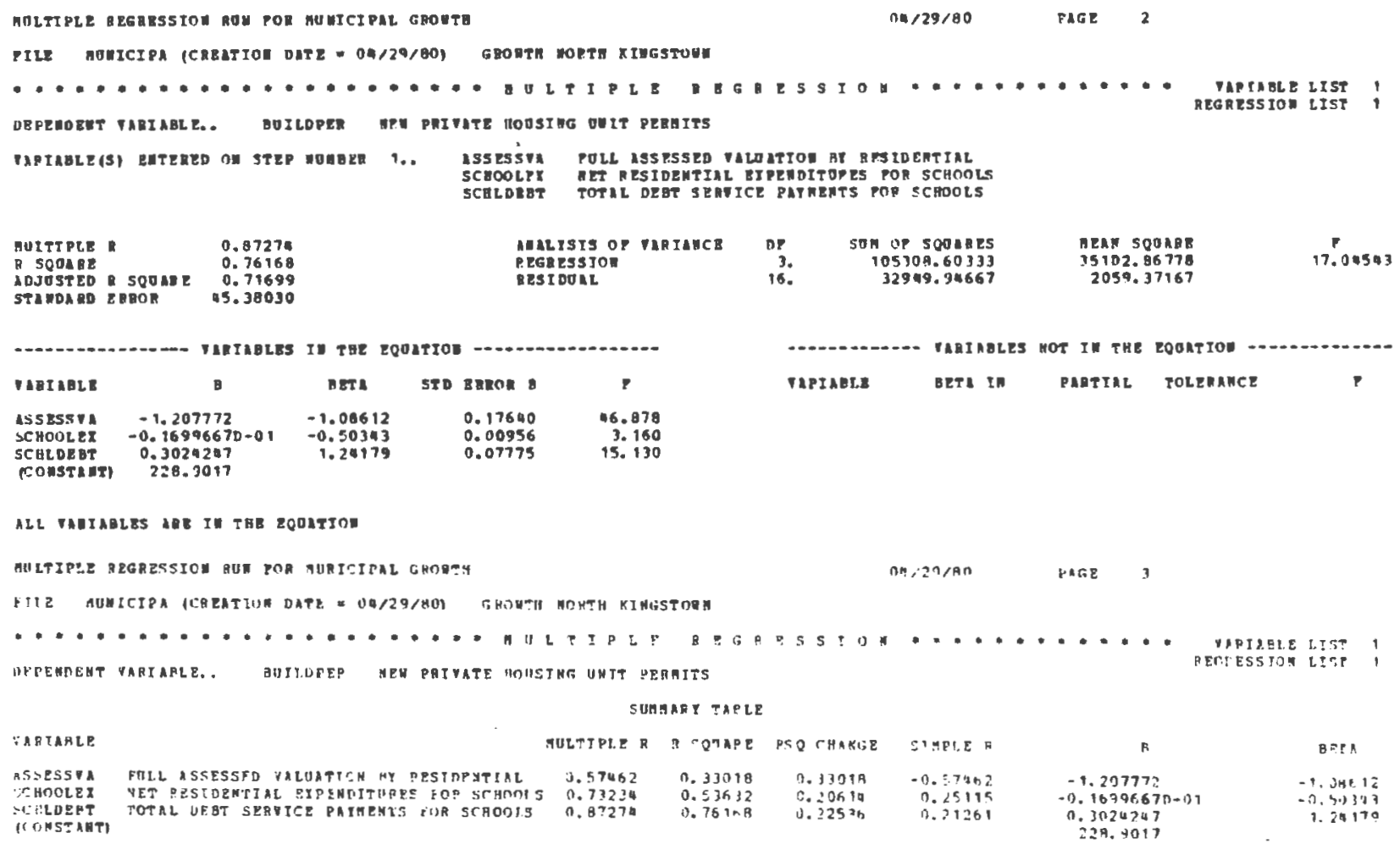




\section{TABLE A-8 (CONTINUED)}

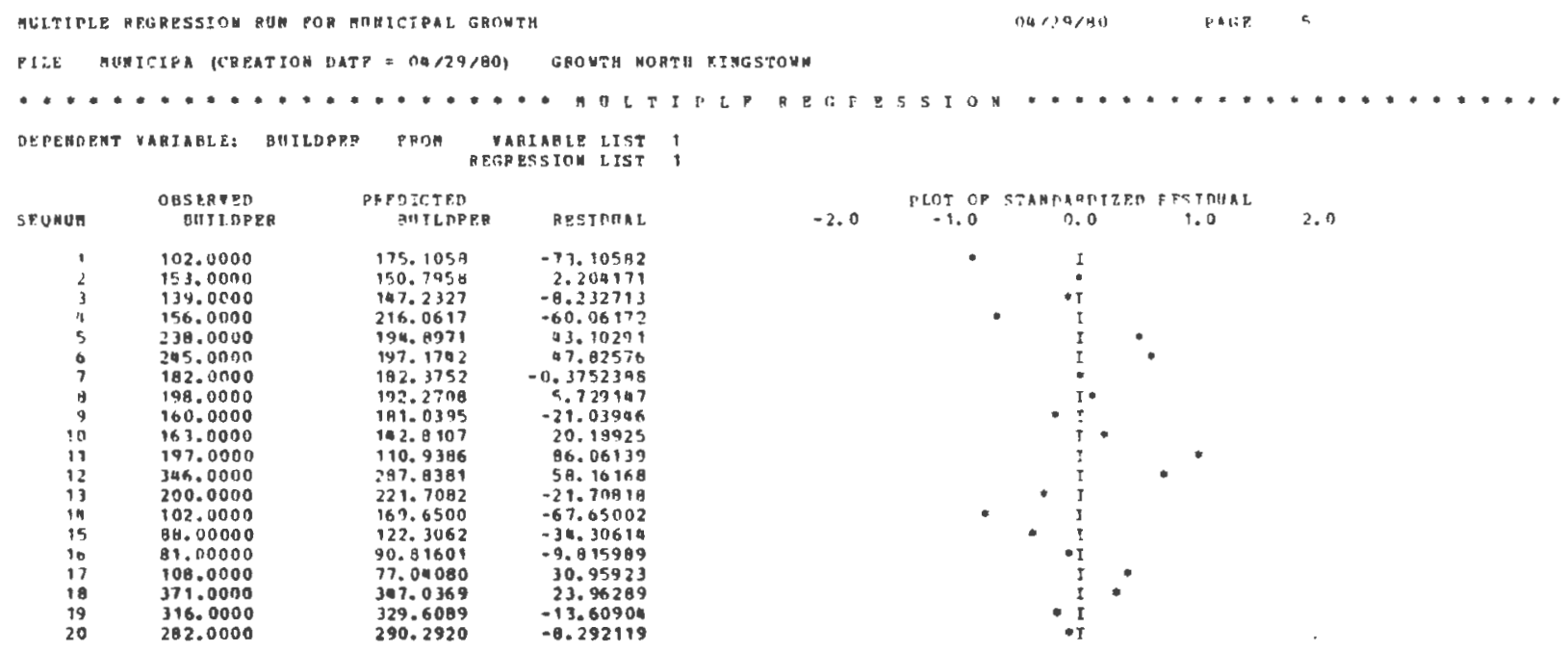

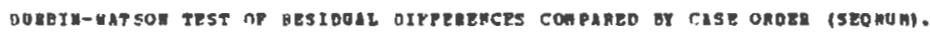

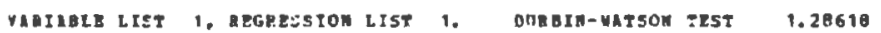

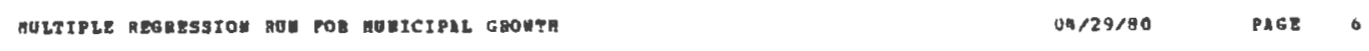

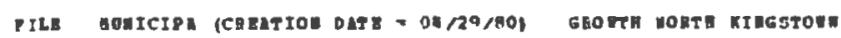

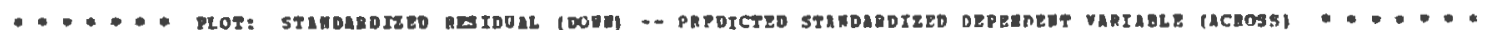

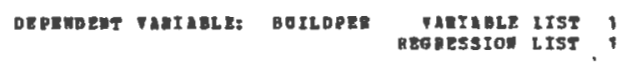

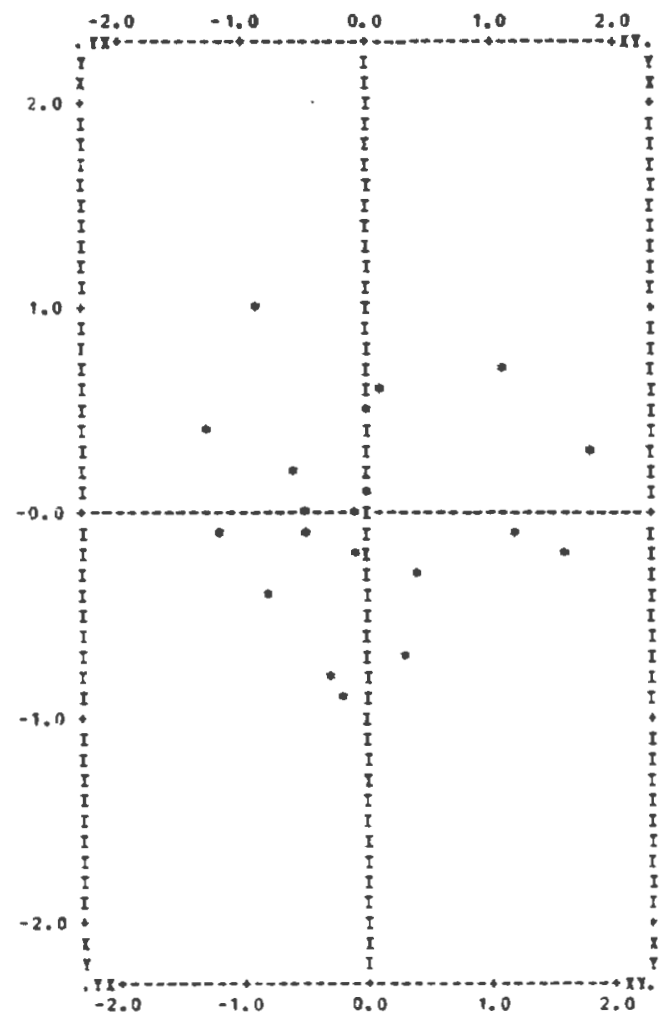

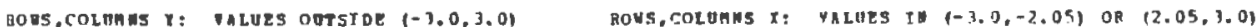




\section{TABLE A-9}

JAMESTOWN

SPSS antCa STSTFh

on rorgn past 1

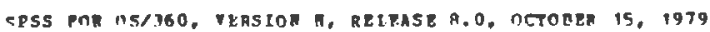

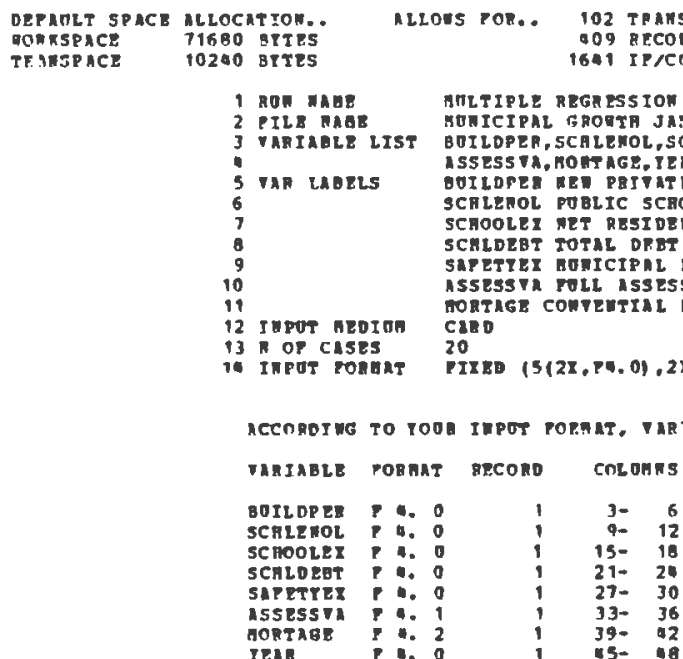

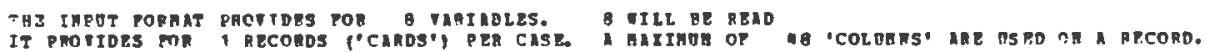

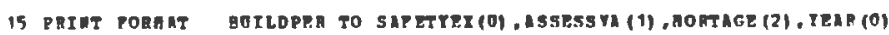

16 RAW OOTPOT OHITY

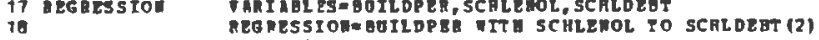

$\begin{array}{ll}20 & \text { Optzons } \\ 21 \text { STMTISTICS } & 0,5,6\end{array}$

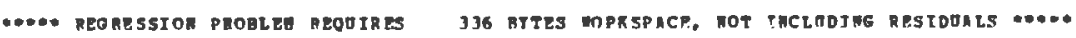

22 READ ITPET DATA

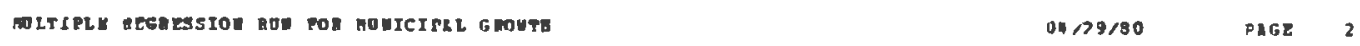

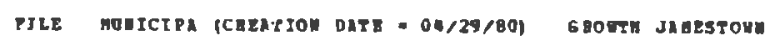

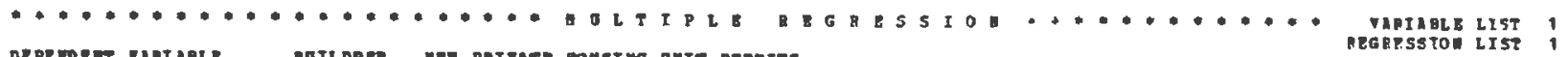

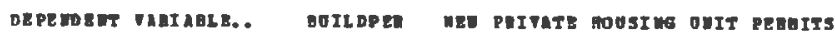

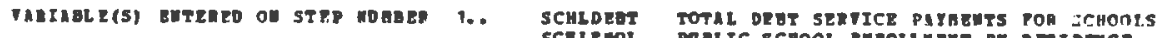

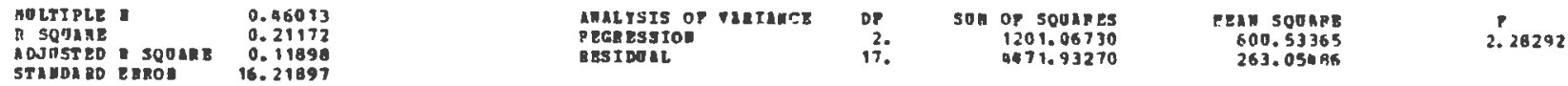

-

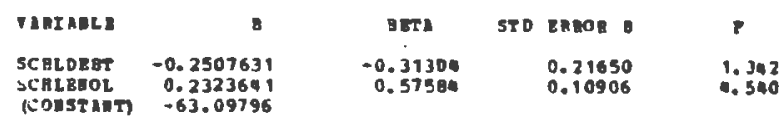

ALL THETASLS ARE II THE EOUATION

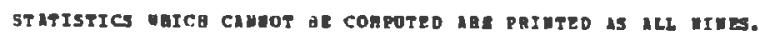

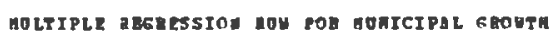

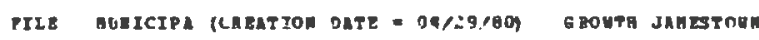

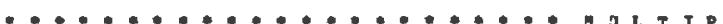

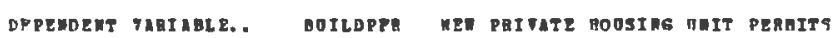

SOHA AR I TACE

\begin{tabular}{|c|c|c|c|c|c|c|c|c|}
\hline TAQRADE & & & GULTIPLE & - SQUARE & ASO CRAMGE & SISPLE & 8 & BEFR \\
\hline $\begin{array}{l}\text { SCHLDEUT } \\
\text { SCBLPNCL }\end{array}$ & $\begin{array}{l}\text { TOTAL OEQT SEHVICE PATHEMTS } \\
\text { POBLIC SCBOOL EMBOLLABMT PT }\end{array}$ & $\begin{array}{l}\text { POR SCHOOLS } \\
\text { RES IOEMCE }\end{array}$ & $\begin{array}{l}0.03495 \\
0.46011\end{array}$ & $\begin{array}{l}0.00122 \\
0.21172\end{array}$ & $\begin{array}{l}0.00122 \\
0.21050\end{array}$ & $\begin{array}{l}0.07495 \\
0.38667\end{array}$ & $\begin{array}{r}-0.2507631 \\
0.2323641\end{array}$ & $\begin{array}{r}-0.91304 \\
0.51584\end{array}$ \\
\hline (CONSTANT) & & & & & & & -63.09796 & \\
\hline
\end{tabular}




\section{TABLE A-9 (CONTINUED)}

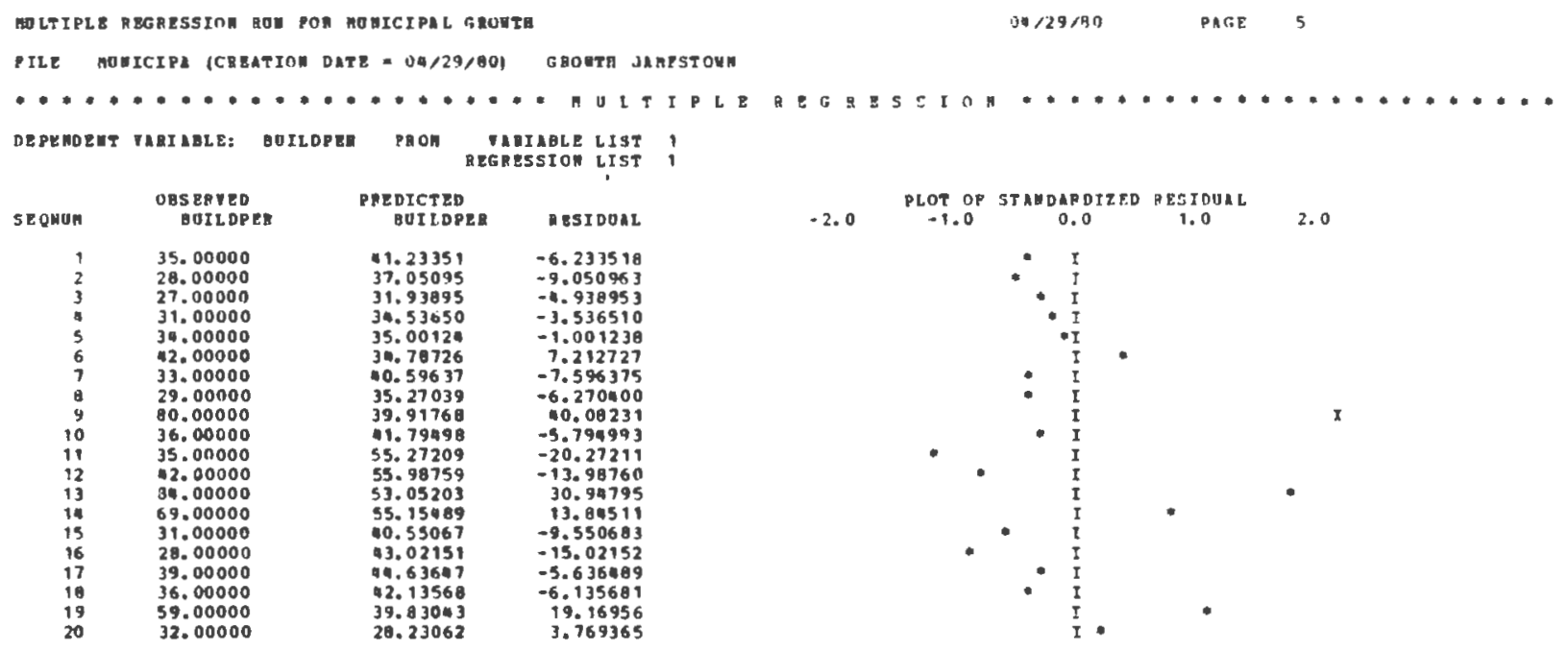

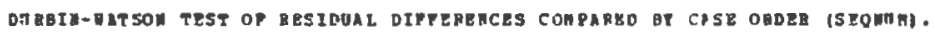

vHATABLE LIST 1, REGRESTON LIST 1. DORBTB-PATSOA TEST 1.9407B

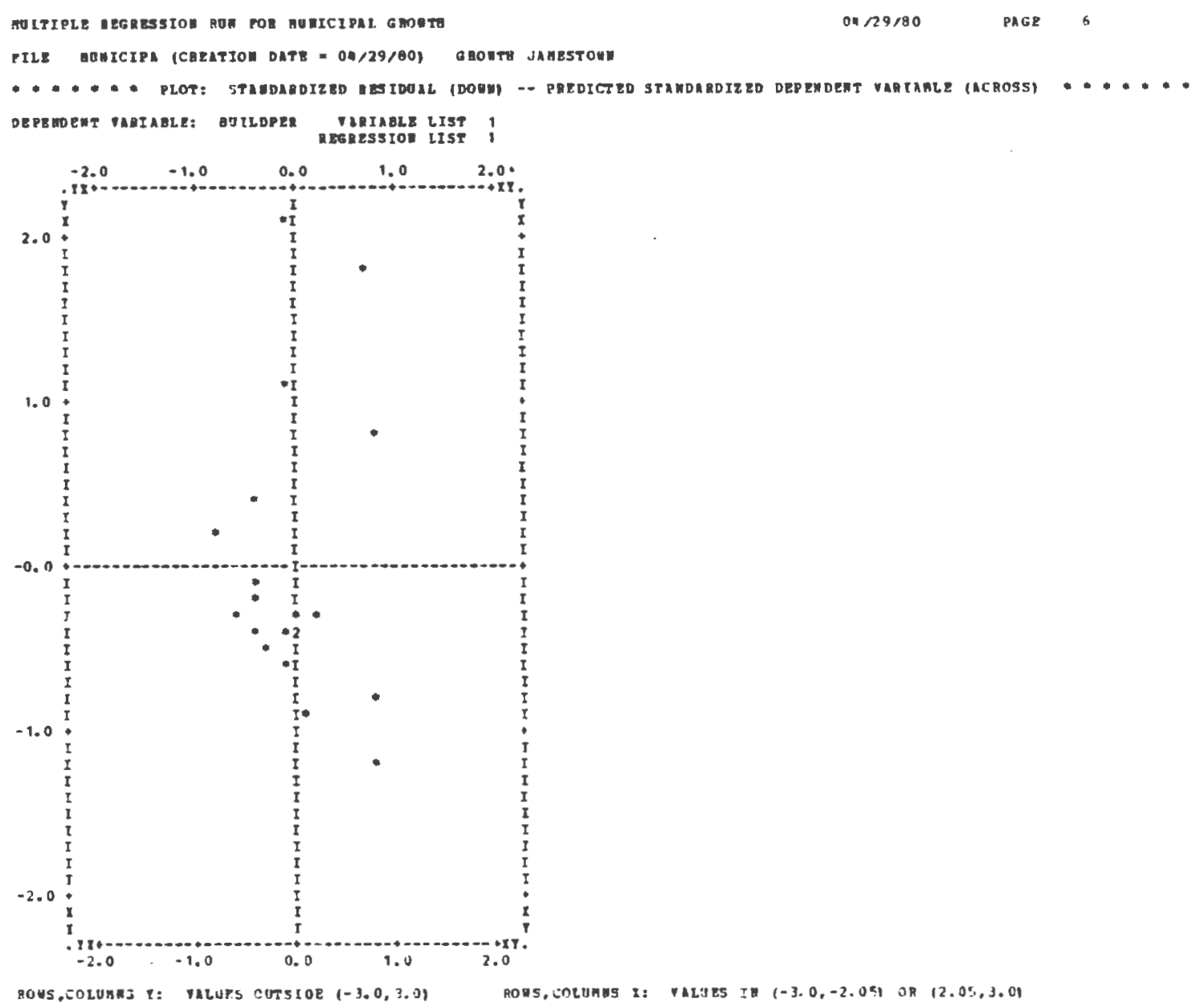


TABLE A-10

Student's $t$-Distribution

Entries in the table are critical vaiues of $t$ for which area in tail of the distribution is $\alpha$.

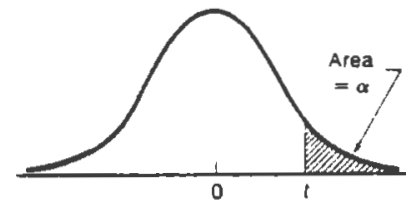

\begin{tabular}{|c|c|c|c|c|c|c|}
\hline \multirow{2}{*}{$\begin{array}{l}\text { Number } \\
\text { of Degrees } \\
\text { of Freedom }\end{array}$} & \multicolumn{6}{|c|}{ Value of $\alpha$} \\
\hline & 0.25 & 0.10 & 0.050 & 0.025 & 0.010 & 0.005 \\
\hline 1 & 1.000 & 3.078 & 6.314 & 12.706 & 31.821 & 63.657 \\
\hline 2 & 0.816 & 1.886 & 2.920 & 4.303 & 6.965 & 9.925 \\
\hline 3 & 0.765 & 1.638 & 2.353 & 3.182 & 4.541 & 5.841 \\
\hline 4 & 0.741 & 1.533 & 2.132 & 2.776 & 3.747 & 4.604 \\
\hline 5 & 0.727 & 1.476 & 2.015 & 2.571 & 3.365 & 4.032 \\
\hline 6 & 0.718 & 1.440 & 1.943 & 2.447 & 3.143 & 3.707 \\
\hline 7 & 0.711 & 1.415 & 1.895 & 2.365 & 2.998 & 3.499 \\
\hline 8 & 0.706 & 1.397 & 1.860 & 2.306 & 2.896 & 3.355 \\
\hline 9 & 0.703 & 1.383 & 1.833 & 2.262 & 2.821 & 3.250 \\
\hline 10 & 0.700 & 1.372 & 1.812 & 2.228 & 2.764 & 3.169 \\
\hline 11 & 0.697 & 1.363 & 1.796 & 2.201 & 2.718 & 3.106 \\
\hline 12 & 0.695 & 1.356 & 1.782 & 2.179 & 2.681 & 3.055 \\
\hline 13 & 0.694 & 1.350 & 1.771 & 2.160 & 2.650 & 3.012 \\
\hline 14 & 0.692 & 1.345 & 1.761 & 2.145 & 2.624 & 2.977 \\
\hline 15 & 0.691 & 1.341 & 1.753 & 2.131 & 2.602 & 2.947 \\
\hline 16 & 0.690 & 1.337 & 1.746 & 2.120 & 2.583 & 2.921 \\
\hline 17 & 0.689 & 1.333 & 1.740 & 2.110 & 2.567 & 2.898 \\
\hline 18 & 0.688 & 1.330 & 1.734 & 2.101 & 2.552 & 2.878 \\
\hline 19 & 0.688 & 1.328 & 1.729 & 2.093 & 2.539 & 2.861 \\
\hline 20 & 0.687 & 1.325 & 1.725 & 2.086 & 2.528 & 2.845 \\
\hline 21 & 0.686 & 1.323 & 1.721 & 2.080 & 2.518 & 2.831 \\
\hline 22 & 0.686 & 1.321 & 1.717 & 2.074 & 2.508 & 2.819 \\
\hline 23 & 0.685 & 1.319 & 1.714 & $2.060^{\circ}$ & 2.500 & 2.807 \\
\hline 24 & 0.685 & 1.318 & 1.711 & 2.064 & 2.492 . & 2.797 \\
\hline 25 & 0.684 & 1.316 & 1.708 & 2.060 & 2.485 & 2.787 \\
\hline 26 & 0.684 & 1.315 & 1.706 & 2.056 & 2.479 & 2.779 \\
\hline 27 & 0.684 & 1.314 & 1.703 & 2.052 & 2.473 & 2.771 \\
\hline 28 & 0.683 & 1.313 & 1.701 & 2.048 & 2.467 & 2.762 \\
\hline 29 & 0.683 & 1.311 & 1.699 & 2.045 & 2.462 & 2.756 \\
\hline 30 & 0.683 & 1.310 & 1.697 & 2.042 & 2.457 & 2.750 \\
\hline$\infty$ & 0.674 & 1.282 & 1.645 & 1.960 & 2.326 & 2.576 \\
\hline
\end{tabular}

Source: Adapled from A. A. Fisher, Statiedea/ Mothods for Reseerch workers, 15th ed. (New York: Hatner, 1970). Table IV. 
TABIE A-11

Five percentage points of the $\boldsymbol{F}$ distribution

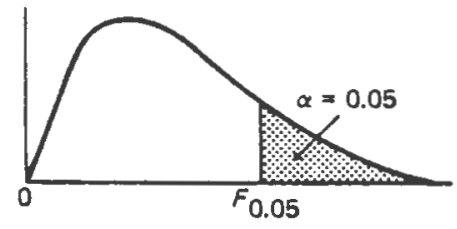

Part 1

\begin{tabular}{|c|c|c|c|c|c|c|c|c|c|}
\hline \multirow{2}{*}{$\begin{array}{c}\text { Degrees of } \\
\text { freedom for } \\
\text { denominator. } \\
\mathrm{df}_{2}\end{array}$} & \multicolumn{9}{|c|}{ Degrees of freedom for numerator, $\mathrm{df}_{\mathrm{q}}$} \\
\hline & 1 & 2 & 3 & 4 & 5 & 6 & 7 & 8 & 9 \\
\hline 1 & 161.45 & 199.50 & 215.71 & 224.58 & 230.16 & 233.99 & 236.77 & 238.88 & 240.54 \\
\hline 2 & 18.51 & 19.00 & 19.16 & 19.25 & 19.30 & 19.33 & 19.35 & 19.37 & 19.38 \\
\hline 3 & 10.13 & 9.55 & 9.28 & 9.12 & 9.01 & 8.94 & 8.89 & 8.85 & 8.81 \\
\hline 4 & 7.71 & 6.94 & 6.59 & 6.39 & 6.26 & 6.16 & 6.09 & 6.04 & 6.00 \\
\hline 5 & 6.61 & 5.79 & 5.41 & 5.19 & 5.05 & 4.95 & 4.88 & 4.82 & 4.77 \\
\hline 6 & 5.99 & 5.14 & 4.76 & 4.53 & 4.39 & 4.28 & 4.21 & 4.15 & 4.10 \\
\hline 7 & 5.59 & 4.74 & 4.35 & 4.12 & 3.97 & 3.87 & 3.79 & 3.73 & 3.68 \\
\hline 8 & 5.32 & 4.46 & 4.07 & 3.84 & 3.69 & 3.58 & 3.50 & 3.44 & 3.39 \\
\hline 9 & 5.12 & 4.26 & 3.86 & 3.63 & 3.48 & 3.37 & 3.29 & 3.23 & 3.18 \\
\hline 10 & 4.96 & 4.10 & 3.71 & 3.48 & 3.33 & 3.22 & 3.14 & 3.07 & 3.02 \\
\hline 11 & 4.84 & 3.98 & 3.59 & 3.36 & 3.20 & 3.09 & 3.01 & 2.95 & 2.90 \\
\hline 12 & 4.75 & 3.89 & 3.49 & 3.26 & 3.11 & 3.00 & 2.91 & 2.85 & 2.80 \\
\hline 13 & 4.67 & 3.81 & 3.41 & 3.18 & 3.03 & 2.92 & 2.83 & 2.77 & 2.71 \\
\hline 14 & 4.60 & 3.74 & 3.34 & 3.11 & 2.96 & 2.85 & 2.76 & 2.70 & 2.65 \\
\hline 15 & 4.54 & 3.68 & 3.29 & 3.06 & 2.90 & 2.79 & 2.71 & 2.64 & 2.59 \\
\hline 16 & 4.49 & 3.63 & 3.24 & 3.01 & 2.85 & 2.74 & 2.66 & 2.59 & 2.54 \\
\hline 17 & 4.45 & 3.59 & 3.20 & 2.96 & 2.81 & 2.70 & 2.61 & 2.55 & 2.49 \\
\hline 18 & 4.41 & 3.55 & 3.16 & 2.93 & 2.77 & 2.66 & 2.58 & 2.51 & 2.46 \\
\hline 19 & 4.38 & 3.52 & 3.13 & 2.90 & 2.74 & 2.63 & 2.54 & 2.48 & 2.42 \\
\hline 20 & 4.35 & 3.49 & 3.10 & 2.87 & 2.71 & 2.60 & 2.51 & 2.45 & 2.39 \\
\hline 21 & 4.32 & 3.47 & 3.07 & 2.84 & 2.68 & 2.57 & 2.49 & 2.42 & 2.37 \\
\hline 22 & 4.30 & 3.44 & 3.05 & 2.82 & 2.66 & 2.55 & 2.46 & 2.40 & 2.34 \\
\hline 23 & 4.28 & 3.42 & 3.03 & 2.80 & 2.64 & 2.53 & 2.44 & 2.37 & 2.32 \\
\hline 24 & 4.26 & 3.40 & 3.01 & 2.78 & 2.62 & 2.51 & 2.42 & 2.36 & 2.30 \\
\hline 25 & 4.24 & 3.39 & 2.99 & 2.76 & 2.60 & 2.49 & 2.40 & 2.34 & 2.28 \\
\hline 26 & 4.23 & 3.37 & 2.98 & 2.74 & 2.59 & 2.47 & 2.39 & 2.32 & 2.27 \\
\hline 27 & 4.21 & 3.35 & 2.96 & 2.73 & 2.57 & 2.46 & 2.37 & 2.31 & 2.25 \\
\hline 28 & 4.20 & 3.34 & 2.95 & 2.71 & 2.56 & 2.45 & 2.36 & 2.29 & 2.24 \\
\hline 29 & 4.18 & 3.33 & 2.93 & 2.70 & 2.55 & 2.43 & 2.35 & 2.28 & 2.22 \\
\hline 30 & 4.17 & 3.32 & 2.92 & 2.69 & 2.53 & 2.42 & 2.33 & 2.27 & 2.21 \\
\hline 40 & 4.08 & 3.23 & 2.84 & 2.61 & 2.45 & 2.34 & 2.25 & 2.18 & 2.12 \\
\hline 60 & 4.00 & 3.15 & 2.76 & 2.53 & 2.37 & 2.25 & 2.17 & 2.10 & 2.04 \\
\hline 120 & 3.92 & 3.07 & 2.68 & 2.45 & 2.29 & 2.17 & 2.09 & 2.02 & 1.96 \\
\hline$\infty$ & 3.84 & 3.00 & 2.60 & 2.37 & 2.21 & 2.10 & 2.01 & 1.94 & 1.88 \\
\hline
\end{tabular}


64

TABLE A-11 (CONTINUED)

Five percentage points of the $F$ distribution (contunued)

Part 11

\begin{tabular}{|c|c|c|c|c|c|c|c|c|c|c|}
\hline 10 & 12 & Degre & ces of fre & reedom fe & for the nu & umerator & $r, d f_{q}$ & 120 & d & $\begin{array}{c}\text { Degrees of } \\
\text { freedom for } \\
\text { denominator } \\
\mathrm{df}_{2}\end{array}$ \\
\hline 241.88 & 243.912 & 245.95 & 248.01 & 249.05 & 250.10 & 251.14 & 252.20 & 253.25 & 254.31 & 1 \\
\hline 19.40 & 19.41 & 19.43 & 19.45 & 19.45 & 19.46 & 19.47 & 19.48 & 19.49 & 19.50 & 2 \\
\hline 8.79 & 8.74 & 8.70 & 8.66 & 8.64 & 8.62 & 8.59 & 8.57 & 8.55 & 8.53 & 3 \\
\hline 5.96 & 5.91 & 5.86 & 5.80 & 5.77 & 5.75 & 5.72 & 5.69 & 5.66 & 5.63 & 4 \\
\hline 4.74 & 4.68 & 4.62 & 4.56 & 4.53 & 4.50 & 4.46 & 4.43 & 4.40 & 4.36 & 5 \\
\hline 4.06 & 4.00 & 3.94 & 3.87 & 3.84 & 3.81 & 3.77 & 3.74 & 3.70 & 3.67 & 6 \\
\hline 3.64 & 3.57 & 3.51 & 3.44 & 3.41 & 3.38 & 3.34 & 3.30 & 3.27 & 3.23 & 7 \\
\hline 3.35 & 3.28 & 3.22 & 3.15 & 3.12 & 3.08 & 3.04 & 3.01 & 2.97 & 2.93 & 8 \\
\hline 3.14 & 3.07 & 3.01 & 2.94 & 2.90 & 2.86 & 2.83 & 2.79 & 2.75 & 2.71 & 9 \\
\hline 2.98 & 2.91 & 2.85 & 2.77 & 2.74 & 2.70 & 2.66 & 2.62 & 2.58 & 2.54 & 10 \\
\hline 2.85 & 2.79 & 2.72 & 2.65 & 2.61 & 2.57 & 2.53 & 2.49 & 2.45 & 2.40 & 11 \\
\hline 2.75 & 2.69 & 2.62 & 2.54 & 2.51 & 2.47 & 2.43 & 2.38 & 2.34 & 2.30 & 12 \\
\hline 2.67 & 2.60 & 2.53 & 2.46 & 2.42 & 2.38 & 2.34 & 2.30 & 2.25 & 2.21 & 13 \\
\hline 2.60 & 2.53 & 2.46 & 2.39 & 2.35 & 2.31 & 2.27 & 2.22 & 2.18 & 2.13 & 14 \\
\hline 2.54 & 2.48 & 2.40 & 2.33 & 2.29 & 2.25 & 2.20 & 2.16 & 2.11 & 2.07 & 16 \\
\hline 2.49 & 2.42 & 2.35 & 2.28 & 2.24 & 2.19 & 2.15 & 2.11 & 2.06 & 2.01 & 16 \\
\hline 2.45 & 2.38 & 2.31 & 2.23 & 2.19 & 2.15 & 2.10 & 2.06 & 2.01 & 1.96 & 17 \\
\hline 2.41 & 2.34 & 2.27 & 2.19 & 2.15 & 2.11 & 2.06 & 2.02 & 1.97 & 1.92 & 18 \\
\hline 2.38 & 2.31 & 2.23 & 2.16 & 2.11 & 2.07 & 2.03 & 1.98 & 1.93 & 1.88 & 19 \\
\hline 2.35 & 2.28 & 2.20 & 2.12 & 2.08 & 2.04 & 1.99 & 1.95 & 1.90 & 1.84 & 20 \\
\hline 2.32 & 2.25 & 2.18 & 2.10 & 2.05 & 2.01 & 1.96 & 1.92 & 1.87 & 1.81 & 21 \\
\hline 2.30 & 2.23 & 2.15 & 2.07 & 2.03 & 1.98 & 1.94 & 1.89 & 1.84 & 1.78 & 22 \\
\hline 2.27 & 2.20 & 2.13 & 2.05 & 2.01 & 1.96 & 1.91 & 1.86 & 1.81 & 1.76 & 23 \\
\hline 2.25 & 2.18 & 2.11 & 2.03 & 1.98 & 1.94 & 1.89 & 1.84 & 1.79 & 1.73 & 24 \\
\hline 2.24 & 2. 16 & 2.09 & 2.01 & 1.96 & 1.92 & 1.87 & 1.82 & 1.77 & 1.71 & 25 \\
\hline 2.22 & 2.15 & 2.07 & 1.99 & 1.95 & 1.90 & 1.85 & 1.80 & 1.75 & 1.69 & 26 \\
\hline 2.20 & 2.13 & 2.06 & 1.97 & 1.93 & 1.88 & 1.84 & 1.79 & 1.73 & 1.67 & 27 \\
\hline 2.19 & 2.12 & 2.04 & 1.96 & 1.91 & 1.87 & 1.82 & 1.77 & 1.71 & 1.65 & 28 \\
\hline 2.18 & 2.10 & 2.03 & 1.94 & 1.90 & 1.85 & 1.81 & 1.75 & 1.70 & 1.64 & 29 \\
\hline 2.16 & 2.09 & 2.01 & 1.93 & 1.89 & 1.84 & 1.79 & 1.74 & 1.68 & 1.62 & 30 \\
\hline 2.08 & 2.00 & 1.92 & 1.84 & 1.79 & 1.74 & 1.69 & 1.64 & 1.58 & 1.51 & 40 \\
\hline 1.99 & 1.92 & 1.84 & 1.75 & 1.70 & 1.65 & 1.59 & 1.53 & 1.47 & 1.39 & 60 \\
\hline 1.91 & 1.83 & 1.75 & 1.66 & 1.61 & 1.55 & 1.50 & 1.43 & 1.35 & 1.25 & 120 \\
\hline 1.83 & 1.75 & 1.67 & 1.57 & 1.52 & 1.46 & 1.39 & 1.32 & 1.22 & 1.00 & $\infty$ \\
\hline
\end{tabular}

Adapted from E. S. Pearson and H. O. Hartloy, Biometrika Tables for Statisticians, Volume II. New York: Cambridge University Press, 178, 1972. 
TABLE A-12

Durbin-Watson Statistic

$$
d=\frac{\sum_{2}^{n}\left(\theta_{t}-\theta_{1-t}\right)^{2}}{\sum_{1}^{n} \theta_{1}{ }^{2}}
$$

Entries in the table are approximations to the critical value of $d$ for which area in lower tail is 0.05 . Area to left of $d_{L}$ is not more than 0.05 ; area to left of $d_{u}$ is at least 0.05 .

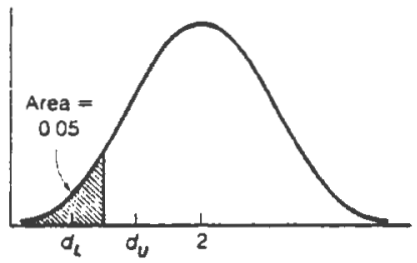

\begin{tabular}{|c|c|c|c|c|c|c|c|c|c|c|}
\hline \multirow{2}{*}{$\begin{array}{c}\text { Number of } \\
\text { Observations } \\
\text { (n) }\end{array}$} & \multicolumn{2}{|c|}{$k=1$} & \multicolumn{2}{|c|}{$k=2$} & \multicolumn{2}{|c|}{$k=3$} & \multicolumn{2}{|c|}{$k=4$} & \multicolumn{2}{|c|}{$k=5$} \\
\hline & $d_{l}$ & $d_{u}$ & $d_{l}$ & $d_{u}$ & $d_{l}$ & $d_{u}$ & $d_{L}$ & $\alpha_{u}$ & $d_{L}$ & $d_{u}$ \\
\hline 15 & 1.08 & 1.36 & 0.95 & 1.54 & 0.82 & 1.75 & 0.69 & 1.97 & 0.56 & 2.21 \\
\hline 16 & 1.10 & 1.37 & 0.98 & 1.54 & 0.86 & 1.73 & 0.74 & 1.93 & 0.62 & 2.15 \\
\hline 17 & 1.13 & 1.38 & 1.02 & 1.54 & 0.90 & 1.71 & 0.78 & 1.90 & 0.67 & 2.10 \\
\hline 18 & 1.16 & 1.39 & 1.05 & 1.53 & 0.93 & 1.69 & 0.82 & 1.87 & 0.71 & 2.06 \\
\hline 19 & 1.18 & 1.40 & 1.08 & 1.53 & 0.97 & 1.68 & 0.86 & 1.85 & 0.75 & 2.02 \\
\hline 20 & 1.20 & 1.41 & 1.10 & 1.54 & 1.00 & 1.68 & 0.90 & 1.83 & 0.79 & 1.99 \\
\hline 21 & 1.22 & 1.42 & 1.13 & 1.54 & 1.03 & 1.67 & 0.93 & 1.81 & 0.83 & 1.96 \\
\hline 22 & 1.24 & 1.43 & 1.15 & 1.54 & 1.05 & 1.66 & 0.96 & 1.80 & 0.86 & 1.94 \\
\hline 23 & 1.26 & 1.44 & 1.17 & 1.54 & 1.08 & 1.66 & 0.99 & 1.79 & 0.90 & 1.92 \\
\hline 24 & 1.27 & 1.45 & 1.19 & 1.55 & 1.10 & 1.66 & 1.01 & 1.78 & 0.93 & 1.90 \\
\hline 25 & 1.29 & 1.45 & 1.21 & 1.55 & 1.12 & 1.66 & 1.04 & 1.77 & 0.95 & 1.89 \\
\hline 30 & 1.35 & 1.49 & 1.28 & 1.57 & 1.21 & 1.65 & 1.14 & 1.74 & 1.07 & 1.83 \\
\hline 35 & 1.40 & 1.52 & 1.34 & 1.58 & 1.28 & 1.65 & 1.22 & 1.73 & 1.16 & 1.80 \\
\hline 40 & 1.44 & 1.54 & 1.39 & 1.60 & 1.34 & 1.66 & 1.29 & 1.72 & 1.23 & 1.79 \\
\hline 50 & 1.50 & 1.59 & 1.46 & 1.63 & 1.42 & 1.67 & 1.38 & 1.72 & 1.34 & 1.77 \\
\hline 60 & 1.55 & 1.62 & 1.51 & 1.65 & 1.48 & 1.69 & 1.44 & 1.73 & 1.41 & 1.77 \\
\hline 70 & 1.58 & 1.64 & 1.55 & 1.67 & 1.52 & 1.70 & 1.49 & 1.74 & 1.46 & 1.77 \\
\hline 80 & 1.61 & 1.66 & 1.59 & 1.69 & 1.56 & 1.72 & 1.53 & 1.74 & 1.51 & 1.77 \\
\hline 90 & 1.63 & 1.68 & 1.61 & 1.70 & 1.59 & 1.73 & 1.57 & 1.75 & 1.54 & 1.78 \\
\hline 100 & 1.65 & 1.69 & 1.63 & 1.72 & 1.61 & 1.74 & 1.59 & 1.76 & 1.57 & 1.78 \\
\hline
\end{tabular}

Source: Adapted from J. Durbin and G. S. Watwon. "Teating for Serial Corralation in Least Squares Alogrecion," Blometrika. 3e(Jume t851):173. Table 4.

Nole: $k$ denotes the number of Independent variables in the regresaion.

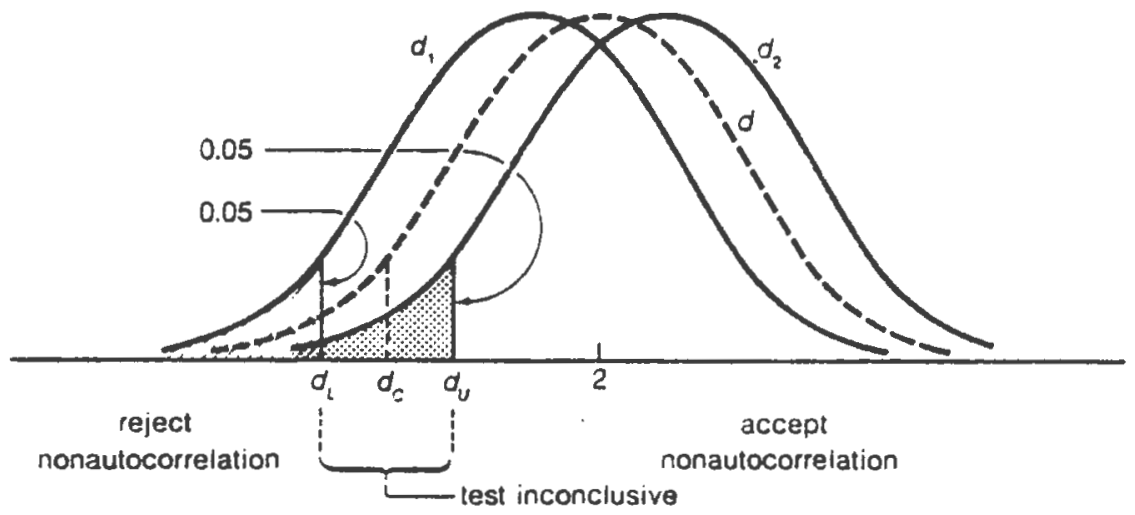

Durbin-Watson test: critical value $d_{c}$ lies between $d_{l}$ and $d_{4}$. 
BIBLIOGRAPHY 
Growth Management

Is sues

Alesch, Daniel, Local Government's Ability to Manage Growth in a Metropolitan Context. Santa Monica:

The Rand Corporation, August 1974.

Ashley, Thomas J. Toward Balanced Urban Growth.

Newport Beach: Ashley Economic Services, Inc., 1972.

Beckman, Norman S. National Growth Policy: Legislation and Executive Action. Washington, D. C.: Urban Land Institute, 1972.

- "Development of National Urban Growth Policy." American Institute of Planners Journal 37 (May 1971): 146-160.

Bourne, Lawrence S. Limits to Urban Growth: Who Benifits, Who Pays, Who Decides?. Toronto: University of Toronto, August 1975.

Boylan, E. S. "Diaster Inducing Elements in Limits to Growth Models." Operations Research 23 ser. 2 (1975): $363-380$.

Finkler, Earl. "Nongrowth As A Planning Alternative: A Preliminary Examination of An Emerging Issue." Planning Advisory Report 283 (1972): $1-65$. 
Finkler, Earl et al. Nongrowth Planning Strategies: The Developing Power of Towns, Cities and Regions. New York: Praeger Publisher, 1974.

Friedly, Philip H. National Policy Responses to Urban Growth. Lexington: Lexington Books, 1974.

Gleeson, Michael E. et al. Urban Growth Management Systems: An Evaluation of Policy Related Research. Planning Advisory Service Nos. 309, 310: American Society of Planning Officials, August 1975.

Godschalk, David R. et al. Constitutional Issues of Growth Management. Chicago: American Society of Planning Officials, 1977.

Harwell, Hugh J. "Growth Management Workshop." Environmental Comment (June 1979) 3-16.

Hoben, James E. "The Cost of Sprawl." HUD Challenge 6 (January 1975) 24-26.

Mace, Ruth L. et al. Do Single Family Homes Pay Their Own Way?. Washington, D. C.: Urban Land Institute, 1976.

Manning, R. "Flexible Utility, Myopic Expectations and Descriptive Growth Theory." Oxford Economic Papers n.s. 27 (1975) 302-305.

Meadows, Dennis L. et al. The Limits of Growth. Washington, D. C.: Potomac Association, 1972.

Scott, Randall W, ed. Management and Control of Growth. 4 vols. Washington, D. C.: Urban Land Institute, 1975. 
Searles, Duane. "Is Growth Good?" HUD Challenge 6 (January 1975): pp. 11-13.

U. S. Advisory Commission on Intergovernmental Relations. Commission Report on Urban and Rural American Policies for Future Growth. Washington, D. C.: Government Printing Office, April 1968.

University of California, Davis. Growth of a Community: Who Wins, Who Loses? Davis, California: University of California Cooperative Extension, 1972.

\section{Substance}

Bourne, Larry S. et al. Urban Futures for Central Canada: Perspectives on Forecasting Urban Growth and Form. Toronto: University of Toronto Press, 1974.

Cook, Robert P. "Growing of a Community." Tennessee Valley Perspective. (Fall 1979): 124 .

Ellickson, Robert C. "Suburban Growth Controls: An Economic and Legal Analysis." Yale Law Journal 86 (January 1977): 385-511.

Hansen, Niles M. Intermediate Size Cities As Growth Centers: Application for Kentucky, the Piedmont Cresent, the Ozarks, and Texas. New York: Praeger Press, 1971.

Harvey, Robert 0. et al. "Controlling Urban Growth: The New Zealand and Australian. Experiment." The Appraisal Journal 32 (October 1964): 551-558. 
Reiner, Edward N. et al. "The Emerging Role of Managed Growth." HUD Challenge. 6 (January 1975): 2-4.

Rust, Edgar. No Growth: Impacts on Netropolitian Areas. Lexington, Massachusetts: D. C. Heath \& Company, 1975.

Schaenman, Philip s. et al. Measuring Impacts of Land Development. Washington, D. C.: The Urban Institute, 1977.

Stockton, David. Fiscal Impact Model I: Theory. Hartford: Connecticut Coastal Area Management Program, 1977.

Methods

Chanoux, Judith M. "The Use of Subdivisions Regulations As a Method of Growth Control: Legal Considerations for Rhode Island." Master's Thesis, University of Rhode Island, 1977.

Dowall, David E. "An Examination of Local Population Growth Control." Ph. D. dissertation, University of Colorado, Boulder, 1975.

Massachusetts Office of State Planning. City and Town Centers: A Program for Growth. Boston: Office of State Planning, September 1977.

Morrison, Peter A. Future Growth and Non-Metropolitan Population: Policies for Coping with Local Decline. Santa Monica, California: The Rand Corporation, 1972.

Peskin, Sarah. Guiding Growth and Change: A Handbook for Massachusetts Citizens. The Appalachian Mountain Club, 1978. 
Robson, Brian T. Urban Growth: An Approach. London: Methuen \& Company, Ltd., 1973.

Barras, R. Designing Computer Programs For Operational Planning Models. London: Centre For Environmental Studies, 1972 .

Batty, Michael. Urban Modelling: Algorithms, Calibrations, and Predictions. Cambridge, England: Cambridge University Press, 1976.

Broadbent, T. A. Notes on the Design of Operational Models. London: Centre For Environmental Studies, 1970.

Lowry, Ira S. A Short Course in Model Design. Santa Monica: The Rand Corporation, 1965.

\section{Miodels}

Baxter, Richard. Urban Development Models. Lancaster, England: University of Cambridge, 1975.

- Urban Systems: The Development of a Cordon Model. Lancaster, England: University of Cambridge, 1970.

Branch, Melville C. "Simulation, Mathematical Models, and Comprehensive City Planning." Urban Affairs Quarterly 1 (March 1966): 15-38.

Brigham, E. F. A Model of Land Residential Values. Santa Monica: The Rand Corporation, 1964.

Casetti, E. "Economic Growth and Population Explosion Simulation Experiments Using Growth Models." Journal of Development Studies 13 (1977): 238-261. 
Chapin, Stuart. "A Model for Simulating Residential Growth." Journal of the American Institute of Planners 31 (May 1965): 120-125.

Czamanski, Stanislaw. "A Model of Urban Growth." Regional Science Association Papers 13 (1964): 177-200.

Donnelly, Thomas G. et al. A Probabilistic Model for Residential Growth. Chapel Hill, North Carolina: Center for Urban and Regional Studies, 1964.

Donnelly, Thomas G. Some Refinements for a Residential Model. Chapel Hill, North Carolina: Center for Urban and Regional Studies, 1965.

Ellson, Richard. "Another Perspective on Growth Management." Urban Land 38 (January 1979): 3-8.

Garrison, William L. "Toward A Simulation of Urban Growth and Development." Human Geography 24 ser. B (1962).

Gortz, E. "Relative Size of Public Sector and Tax Burden in a Neoclassical Growth Model." Scandinavian Journal of Economics 78 (1976): 413-426.

Ihori, T. "Golden Rule and the Role of Government in a Life-Cycle Growth Model." American Econonic Review $68(1978)$ : $389-396$.

Laidlaw, Charles D. Linear Programming for Urban Development Plan Evaluation. New York: Praeger Publishers, 1972.

Lee, Colin. Models in Planning. Oxford, England: Pergamon Press, 1973. 
Little, Dennis L. Models and Simulation: Some Definitions. Middletown, Connecticut: Institute for the Future, 1970.

Lowry, Ira S. Migration and Metropolitan Growth: Two Analytical Models. Los Angeles: Institute of Government and Public Affairs Service, 1966.

Lowry, Ira.S. Seven Models of Urban Development. Santa Monica: The Rand Corporation, 1967.

Mason, Richard P. "A Dynamic Simulation of Urban Growth." $\mathrm{Ph}$. D. dissertation, State University of New York at Buffalo, 1975.

Masser, Ian. Analytical Models for Urban and Regional Planning. New York: David \& Charles Publisher, 1972.

Schneider, Devon M. et al. Computer-Assisted Land Resources Planning. Chicago: Planning Advisory Service, American Planning Association, January 1979.

Starr, Martin K. "Planning Models." Management Science ser. B, (December 1966): 115-141.

Steiss, Alan W. Models for the Analysis and Planning of Urban Systems. Lexington, Massachusetts:

D. C. Heath Company, 1974 .

Wilson, A. G. Developments of Some Elementary Residential Location Models. London: Centre For Environmental Studies, December 1968.

- Metropolitan Growth Models. London: Centre For Environmental Studies, February 1968. 
- Models in Urban Planning: A Synopic Review of Recent Literature. London: Centre For Environmental Studies, February 1968.

- Urban and Regional Models in Geography and Planning. Bristol, England: John Wiley \& Sons, Ltd., 1974 .

Wu, Cy. "Growth Models and Limits-To-Growth Models As Basis For Policymaking in Economic Development." Political Science 5 (1974): 191.

\section{Statistics}

Beals, Ralph E. Statistics For Economists. Chicago: Rand MCNally \& Company, 1972.

Nie, Norman H. et al. Statistical Package For the Social Sciences, 2nd. edition. New York: McGraw-Hill Book Company, 1975.

Smith, H. et al. Applied Regression Analysis. New York: Wiley, 1966.

Tai, Simon $w$. Social Science Statistics: Its Elements and Applications. Santa Monica, California: Goodyear Publishing Company, 1978.

\section{Municipal Expenses}

Alonso, William. The Economics of Urban Size. Berkeley: Center For Planning and Development, University of California, 1976. 
Bradford, D. F. et al. "The Rising Costs of Local Public Service: Some Evidence and Reflections." National Tax Journal 22 (June 1969): pp. 20-24.

Burchell, Robert $w$. et al. The Fiscal Impact Handbook: Estimates of Local Costs and Revenues of Land Development. New Brunswick, New Jersey: Center For Urban Policy Research, 1978.

Gruen Gruen \& Associates. Impacts of Growth: An Analytical Framework and Fiscal Examples. California: The California Better Housing Foundation, 1972.

Hufbauer, G. C. et al. "Municipal Costs and Urban Area." Journal of Urban Economics 2 (July 1975): 199-211.

Isard, Walter, et al. Municipal Costs and Revenues Resulting From Community Growth. Wellesley, Massachusetts: Chandler-Davis Publishers, 1957.

Kracht, James B. "The Measurement of Factors Associated with Selected Expenditures and Their Relation to the Problem of Optimum City-Size." Master's Thesis, Indiana State University, 1969.

Muller, Thomas et al. The Fiscal Impact of Residential and Commercial Development: A Case Study. Washington, D. C.: The Urban Institute, 1972.

Stern, Richard B. et al. "Beware the Pitfalls in Fiscal Impact Analysis." Planning 46 (April 1980): 15-17.

Zycher, Benjamin et al. Municipal Service Pricing: Impact on the Growth of Residential Development. Santa Monica: The Rand Corporation, 1975. 